\title{
Design and biological assembly of polyester beads displaying pneumococcal antigens as particulate vaccine
}

\author{
Majela González-Miró, ${ }^{\mp}$ • Anna-Maria Radecker,' Laura M Rodríguez-Noda, ${ }^{\mp}$ Mildrey \\ Fariñas-Medina, ${ }^{\mp}$ Caridad Zayas-Vignier, ${ }^{\mp}$ Mabel Hernández-Cedeño, ${ }^{\mp}$ Yohana Serrano, ${ }^{\top}$ \\ Félix Cardoso, ${ }^{\mp}$ Darielys Santana-Mederos, ${ }^{\mp}$ Dagmar García-Rivera, ${ }^{\mp}$ Yury Valdés-Balbín, ${ }^{\mp}$ \\ Vicente Vérez-Bencomo, ${ }^{\top}$ Bernd H.A. Rehm, ${ }^{\cdot}, *$ \\ ${ }^{\mathrm{I}}$ Finlay Vaccine Institute, $27^{\text {th }}$ avenue, No19805 between 198 and 202, La Lisa, Havana, \\ Cuba; Institute of Fundamental Sciences, Massey University, Colombo Road, Palmerston \\ North, New Zealand; \\ - Centre for Cell Factories and Biopolymers, Griffith Institute for Drug Discovery, Don \\ Young Road, Nathan, Griffith University, Nathan, Queensland, Australia \\ *E-mail: $\underline{\text { b.rehm@griffith.edu.au. }}$
}


ABSTRACT

Streptococcus pneumoniae can cause life-threatening infections mostly in infants, children and elderly people. Capsular polysaccharide conjugate vaccines provide serotype-dependent protection against $S$. pneumoniae infections but fail to protect against new emerging serotypes. To overcome these limitations, pneumolysin (Ply), a serotype-independent and conserved protein was selected. As such subunit vaccines lack immunogenicity, we engineered Ply to be attached to self-assembled polyester beads in order to boost immunogenicity. To display Ply at the surface of these polyester beads, it was translationally fused to the $N$-terminus of the polyhydroxybutyrate (PHB) synthase (PhaC), which mediates PHB bead assembly inside recombinant Escherichia coli. We also chemically conjugated the capsular polysaccharide (CPS) 19F to isolated PHB beads to further assess their antigen carrier properties. CPS conjugated to soluble tetanus toxoid served as control. Balb/c mice immunized with Ply-PhaC beads and 19F-PhaC beads induced specific and higher IgG levels than the respective soluble counterparts. The induced IgG antibodies recognized Ply in whole cell lysates of six different serotypes of $S$. pneumoniae. Additionally, restimulated splenocytes from animals immunized with Ply-PhaC beads produced a balanced INF- $\mathrm{\gamma} / \mathrm{IL}-$ 17A profile unlike animals immunized with soluble Ply. The 19F-PhaC beads induced production of antibodies showing high opsonophagocytic titers against the homologous strain, serotype 19F, while CPS 19F only mixed with PhaC beads did not elicit any detectable immune response. This study provided insight into the design of PHB beads as a carrier of proteinaceous antigens and CPS in order to induce immune responses for the prevention of pneumococcal infections.

Keywords: Particulate vaccine, capsular polysaccharides, antigen delivery, polyhydroxybutyrate, self-assembly, pneumolysin 

various virulent strains. ${ }^{2-4}$

Polysaccharide-immunogenic carrier protein conjugate vaccines are widely used to prevent pneumococcal diseases around the world. There are three licensed vaccines in the market (Prevnar 7, Prevnar 13 and Synflorix), which include important serotypes such as 1, 3, $4,5,6 \mathrm{~B}, 7 \mathrm{~F}, 9 \mathrm{~V}, 19 \mathrm{~F}, 23 \mathrm{~F}$ and $18 \mathrm{C}$. All of them show a safe and serotype-specific immune response profile. ${ }^{3,5-6}$ As the CPS composition limits, the efficacy of these vaccines , emerging serotypes require alternative vaccination strategies. ${ }^{3}$ Proteins such as the pneumococcal surface protein A (PspA), pneumococcal surface adhesin A (PsaA), pneumolysin (Ply) and pneumococcal surface protein $\mathrm{C}$ (PspC) have been shown to elicit broadly protective immune responses. $^{7-9}$ Ply is a $53 \mathrm{kDa}$ protein produced by all of the isolated S. pneumoniae strains. ${ }^{10}$ This protein belongs to a group of cytoplasmic thiol-activated lysins and plays a role in the colonization process as well as contributing to severe lung tissue damage in later stages of infection. ${ }^{11-13}$ It has also been shown to induce strong cytokine production such as IL-17A associated with the recruitment of neutrophils to the damaged tissue. ${ }^{14}$ Because of its relevance as a virulence factor and its immunological properties, Ply has been considered as a vaccine candidate antigen to prevent pneumococcal diseases. ${ }^{15}$ However, as a subunit vaccine, purified soluble Ply by itself is poorly immunogenic requiring the addition of adjuvant as part of the vaccine formulation in order to induce protective immunity. 
Displaying or entrapping antigens in cell-free carrier/delivery systems such as polymeric micro-/nano-particles, liposomes and virus-like particles, have been an effective strategy boosting a specific immune response. ${ }^{16-20}$ Recently, delivery systems such as a polylactic-coglycolic acid (PLGA) nanocarrier, chitosan nanoparticles and polyhydroxybutyrate (PHB) beads presented advantageous properties regarding induction of humoral and cellular immune responses. $^{21-22}$

Polyhydroxybutyrate (PHB) is the best known polyester naturally produced as cellular inclusions by various bacteria. ${ }^{23}$ The introduction of three genes encoding the main enzymes involved in the PHB biosynthesis pathways in not naturally PHB producing bacteria, like E.coli, enabled the recombinant production of these PHB beads exhibiting diameters of about $500 \mathrm{~nm}-1 \mu \mathrm{m} .{ }^{24-25}$ Translational fusions of foreign proteins to the PHB synthase mediated the production of PHB inclusions coated with the respective proteins of interest. ${ }^{22-23,}{ }^{26-30} \mathrm{PHB}$ beads displaying selected antigens served as antigen delivery system and induced protective immune responses against intracellular pathogens such as e.g. Mycobacterium tuberculosis and Hepatitis $\mathrm{C}$ as well as a strong and specific immune response against the extracellular pathogens S. pneumoniae, Neisseria meningitidis and Pseudomonas aeruginosa. ${ }^{28-29,31-34}$ In this study, the aims were to display Ply and CPS from serotype 19F on PHB beads and to study the humoral and cellular immune responses after vaccination. This proof of concept study could enable the future design and production of novel multivalent particulate vaccines for prevention of $S$. pneumoniae infections.

\section{- MATERIALS AND METHODS}

Strains and cultivation conditions. E. coli XL1 blue was used as a plasmid propagation host and cultivated in Luria Bertani broth (LB) containing $100 \mu \mathrm{g} / \mathrm{mL}$ of ampicillin at $37^{\circ} \mathrm{C}$. 
PHB beads and soluble His-tagged protein were produced in an endotoxin-free E. coli strain ClearColi. ${ }^{34-35}$

\section{Construction of plasmids for production of soluble Ply and Ply displayed on PHB}

beads. The gene encoding the non-toxic Ply (470aa, selected from $S$. pneumoniae strain R36A and with a double mutation (G293T, C428A)) was synthesised as codon optimized for expression in E. coli. ${ }^{36-37}$ The ply gene was amplified from pUC57-ply by PCR and hydrolyzed with (XbaI/SpeI) restriction enzymes. The respective Ply encoding DNA fragment was then inserted into the 5 'end of the phaC gene. To produce soluble Ply, six CAC codons were introduced to 5 ' end of the gene to encode six histidine residues for purification by $\mathrm{Ni}^{2+}$ affinity chromatography. The hybrid genes encoding proteins, used in this study are outlined in Fig. 1, while the oligonucleotides and plasmids are listed in Table 1. The ply gene sequence was confirmed by DNA sequencing of final plasmids.

Table 1. Characteristics of plasmids and oligonucleotides used in this study.

\begin{tabular}{|c|c|c|}
\hline Plasmid and primers & Characteristics & Reference \\
\hline \multicolumn{3}{|l|}{ Plasmids } \\
\hline pET-14b & $A p^{R}$ and $\mathrm{T} 7$ promoter & Novagen \\
\hline pET-14b-phaC & pET-14b version, holding $p h a C$ gene fragment & 38 \\
\hline pUC57-ply & pUC57 version, ColE1 origin, $A p^{R}$ holding ply gene. & GenScript \\
\hline pMCS69 & $\begin{array}{l}\mathrm{Cm}^{R} ; \text { T7 promoter, pBBR1MCS derivative containing } \\
\text { phaA and phaB genes from Ralstonia eutropha co- } \\
\text { downstream to lac promoter }\end{array}$ & 39 \\
\hline $\begin{array}{l}\text { pET14b_NanA_PhaC } \\
\text { (reversed) }\end{array}$ & $\begin{array}{l}A p^{R} \text { and } \mathrm{T} 7 \text { promoter, containing nanA gene cloned to } 3 \text { ' } \\
\text { end of } p h a C\end{array}$ & 27 \\
\hline pET-14b-ply-phaC & $\begin{array}{l}\text { pET-14b-phaC version, holding ply gene fused to } 3 \text { ' end of } \\
\text { phaC }\end{array}$ & This study \\
\hline pET14b- his6-ply & $\begin{array}{l}A p^{R} \text { and } \mathrm{T} 7 \text { promoter, containing the his6-ply gene inserted } \\
\text { into the } X b a \mathrm{I} / / \mathrm{BamH} \text { I sites of pET14b. }\end{array}$ & This study \\
\hline \multicolumn{3}{|l|}{ Oligonucleotides } \\
\hline Ply $X b a$ I fwr & $\begin{array}{l}\text { 5’AAATCTAGAAATAATTTTGTTTAACTTTAAGAAG } \\
\text { GAGATATCATATGGCAAATAAAGCTGTTAATGATT } \\
\text { TTATTCTTGCTATGAATTATGAT3' }\end{array}$ & This study \\
\hline Ply SpeI rev & 5'AAAACTAGTATCATTTTCTACTTTATCTTCTACTT & This study \\
\hline
\end{tabular}


GAGGATACAATGTTGTTCCCC3

Ply $X b a$ I Hist-tag fwr 5'AAATCTAGAAATAATTTTGTTTAACTTTAAGAAG This study GAGATATCATATGCATCATCATCATCATCATGCAA ATAAAGCTGTTAATGATTTTATTCTTGCTATGAATT ATGAT3'

Ply BamHI rev 5'CCCGGATCCTCAATCATTTTCTACTTTATCTTCTA This study CTTGAGGATACAATGTTGTTCCCC 3'

PHB bead production. The PHB bead production, isolation, purification, sterilization and determination of final ratio $\mu \mathrm{g}$ of $\mathrm{Ply}$ or $\mathrm{PhaC} / \mathrm{mg}$ of wet beads were conducted as described previously. ${ }^{31,}$ 40-42 In this study, E. coli (ClearColi) harboring pMCS69 was transformed with pET14b-ply-phaC for the production of the Ply displaying PHB beads (PlyPhaC beads) and with pET14b-phaC to produce non-antigen displaying PHB beads (PhaC beads).

Production of soluble Ply. The E. coli (ClearColi) harboring with pET-14b-his6-ply plasmid was cultivated at $25^{\circ} \mathrm{C}$ at $200 \mathrm{rpm}$ for $24 \mathrm{~h}$. The cells were lysed by mechanical disruption and purified by $\mathrm{Ni}^{2+}$ chromatography according to the manufacturer's protocol (HisTrapTM FF crude, GE Healthcare-Bio-Sciences AB, Sweden). The protein concentrations of His6-Ply was determined by BCA colorimetric assay (Pierce ${ }^{\mathrm{TM}}$ BCA Protein Assay Kit). ${ }^{43}$

Conjugation of CPS to PHB beads. The CPS from S. pneumoniae serotype 19F, tetanus toxoid (TT) were provided by the Finlay Institute (Havana, Cuba). Both were produced under Good Manufacture Practice and passed all of the WHO's recommended quality controls. ${ }^{44}$ The chemical conjugation of the CPS to PHB beads as well as TT was performed as described elsewhere. ${ }^{45}$ Protein and carbohydrate concentration was determined by Lowry and Phenol-Sulfuric acid assays. ${ }^{46-47}$

Transmission electron microscopy (TEM) and Gas chromatography-mass spectrometry (GC/MS) analysis. To demonstrate production of PHB beads by E. coli 
(ClearColi), cells harboring pET14b-ply-phaC or pET14b-phaC were washed with PBS (pH 7.0) and analysed by TEM. ${ }^{35}$ The presence of spherical inclusion inside of the cells indicated functionality of PhaC. Isolated PHB beads were analysed by (GC/MS) ${ }^{48}$ and TEM to assess the polyester content, purity and size distribution, respectively.

Measurement of PHB bead surface charge. The surface charge of PHB beads was measured using the Zetasizer Nano ZS (Malvern Instrument, United Kingdom). Samples were prepared as $0.1 \%(\mathrm{w} / \mathrm{v})$ of the wet PHB beads in saline solution. The $\mathrm{pH}$ values were adjusted with $\mathrm{HCl}$.

Proteins analysis by SDS-PAGE and immunoblot. Proteins associated with PHB beads as well as soluble Ply were analysed by sodium dodecyl sulphate acrylamide gel electrophoresis (SDS-PAGE). ${ }^{49-50}$ Samples were mixed with loading buffer and incubated for $15 \mathrm{~min}$ at $95^{\circ} \mathrm{C}$. For PHB beads $10 \%(\mathrm{w} / \mathrm{v})$ suspension was used, while for His6-Ply the final protein concentration was $0.06 \mathrm{mg} / \mathrm{mL}$. To identify proteins, protein bands were excised from the SDS-PAGE gel and subjected to tryptic peptide fingerprinting analysis using liquid chromatography tandem-mass spectroscopy including TripleTOF analysis. ${ }^{51}$ Further identification of proteins was obtained by immunoblotting using monoclonal antibodies against Ply (PLY-7, IgG1 (к)) and monospecific polyclonal anti-PhaC antibodies. ${ }^{52-53}$

Animal ethics. This study was carried out in accordance with the Finlay Vaccine Institute animal ethics guidelines and international recommendations. The protocols were approved by the ethics committee of the Finlay Vaccine Institute (Cuba). Written informed consent was obtained from human blood donors, Majela González-Miró and Laura M Rodríguez-Noda, for isolation of PMNs to be used in the opsonophagocytic assay.

Immunization schedule for Ply containing vaccine formulations. Four immunization groups comprising each eight animals between 5-6 weeks old (male, Balb/c mice) were prepared. Mice were acquired from CENPALAB (Centro Nacional para la Producción de 
Animales de Laboratorio, La Habana, Cuba). Three vaccination doses of $1.5 \mu \mathrm{g}$ of antigen, Ply or PhaC, plus $15 \mu \mathrm{g}$ of alum (ALHYDROGEL, Brenntag Biosector, Denmark) were subcutaneously administered to each animal (Table 2). Animals of the placebo group received only the adjuvant. Immunizations occurred at 0,14 and $28 \mathrm{~d}$. Blood samples were collected from the retro-orbital plexus at day 0 and seven days after the last immunization (35 days).

Table 2. Immunization groups, vaccines features

\begin{tabular}{|l|c|c|c|c|}
\hline $\begin{array}{l}\text { Immunization } \\
\text { Group }\end{array}$ & $\begin{array}{c}\text { Ply } \\
\text { dose } \\
(\mu \mathrm{g} / \text { mouse })\end{array}$ & $\begin{array}{c}\text { Alum } \\
\text { dose } \\
(\mu \mathrm{g} / \text { mouse })\end{array}$ & $\begin{array}{c}\text { PhaC } \\
\text { dose } \\
(\mu \mathrm{g} / \mathrm{mouse})\end{array}$ & $\begin{array}{c}\text { PHB beads } \\
(\mathrm{mg} / \mathrm{mouse})\end{array}$ \\
\hline Ply-PhaC beads & 1.5 & 15 & 1.83 & 10.56 \\
\hline His6-Ply & 1.5 & 15 & 0 & 0 \\
\hline PhaC beads & 0 & 15 & 1.5 & 3.75 \\
\hline $\begin{array}{l}\text { Alum } \\
\text { (adjuvant) }\end{array}$ & 0 & 15 & 0 & 0 \\
\hline
\end{tabular}

Preliminary assessment of the safety of each formulation showed lump (about $2 \mathrm{~mm}$ ) formation at the injection sites when animals were immunized with PHB beads. Mouse weights between groups showed no significant variation and all mice steadily gained weight during the time-course of the experiment. In addition, after euthanasia, vital organs were observed and showed no obvious deviation from the vaccine groups compared with the adjuvant group.

Immunization schedule for CPS containing vaccine formulations. Four immunization groups comprising each eight animals were used as described above. Three vaccination doses between $2-10 \mu \mathrm{g}$ of 19F CPS were subcutaneously administered to each animal (Table 3). Immunizations and blood sample collections were conducted as above, except that one more blood collection was performed at six months after the last immunization. At the end of the immunization schedule, an SDS-PAGE analysis (Ply-PhaC, PhaC and His6-Ply) and an 
ELISA (19F-PhaC and 19F-TT) with samples from the original isolation of PHB beads confirmed the stability of vaccine formulations during the immunization schedule.

Table 3. Immunization groups, vaccines features

\begin{tabular}{|l|c|c|c|}
\hline $\begin{array}{l}\text { Immunization } \\
\text { Group }\end{array}$ & $\begin{array}{c}\text { 19F CPS dose } \\
(\mu \mathrm{g} / \text { mouse })\end{array}$ & $\begin{array}{c}\text { Alum } \\
(\mu \mathrm{g} / \text { mouse })\end{array}$ & $\begin{array}{c}\text { PhaC } \\
(\mu \mathrm{g} / \text { mouse })\end{array}$ \\
\hline 19F-PhaC beads & 2 & 125 & 5.4 \\
\hline 19F-TT & 2 & 125 & \\
\hline 19F CPS + PhaC bead & $10^{54}$ & 125 & 30 \\
\hline Alum (adjuvant) & 0 & 125 & \\
\hline
\end{tabular}

Evaluation of anti-Ply IgG antibody levels by ELISA. The anti-Ply IgG titers were evaluated as mentioned previously but with minor deviations. ${ }^{31}$ Briefly, plates were coated with $0.2 \mu \mathrm{g} / \mathrm{mL}$ of His6-Ply in coating buffer. The serum of each mouse, at time 0 and $7 \mathrm{~d}$ after the last immunization was serially diluted, in duplicate, and started at a dilution of 100 and 800 , respectively. All sera were incubated in the plate for 90 min at $25^{\circ} \mathrm{C}$. Anti-mouse IgG peroxidase conjugate (Sigma-Aldrich, St. Louis, MO) was diluted 1: 10,000 and incubated as mentioned above. A serum was considered as positive if the absorbance of the initial dilution was 2-fold greater than with the pre-immune serum of the same animal. The IgG titer was estimated by linearly interpolating the data between the highest dilution giving at least $50 \%$ of the maximum (plateau) absorbance and the next dilution. ${ }^{30,34}$ The results are shown as the mean \pm SEM of 8 animals.

Evaluation of anti-19F IgG antibody levels by ELISA. Briefly, plates were coated with $10 \mu \mathrm{g} / \mathrm{mL}$ of the CPS from serotype $19 \mathrm{~F}$ in PBS pH 7.0. The serum of each mouse, at time $0,7 \mathrm{~d}$ and 6 months after the last vaccination was serially diluted, in duplicate, starting with a dilution of 100. While anti-mouse IgG peroxidase conjugate (Sigma-Aldrich, St. 
Louis, MO) was diluted 1: 10,000, all sera were incubated in wells of plates for 90 min at 25 ${ }^{\circ} \mathrm{C}$. A serum was considered as positive if the absorbance of the initial dilution was 2-fold greater than with the pre-immune serum of the same animal. The IgG titer was estimated by linearly interpolating the data between the highest dilution giving at least $50 \%$ of the maximum (plateau) absorbance and the next dilution. ${ }^{30,34}$ The results are shown as the mean \pm SEM of 8 animals.

Analysis of the anti-Ply Ig isotype profile by ELISA. The ELISA was performed as described above and serum from each animal 7 days after the last immunization was serially diluted, in duplicate, starting at a dilution of 200. The anti-IgG1, IgG2a, IgG2b, IgG3 and IgM antibodies were derived from goat (Sigma-Aldrich, St. Louis, MO) and diluted 1: 2500. The IgG titer was calculated as described above. The results are shown as the mean $\pm \mathrm{SEM}$ of 8 animals.

Cytokine Assay. Mice were euthanised and spleens were removed from each mouse 7 days after the last immunization dose, cells were recovered by perfusion and pooled for each group. Erythrocytes were then removed by osmotic shock using $0.2 \%$ (w/v) $\mathrm{NaCl}^{34,55}$ The cells were counted, and the viability was tested by trypan blue exclusion staining. Splenocytes were adjusted to $4 \times 10^{6}$ cells $/ \mathrm{mL}$ and were cultured for $96 \mathrm{~h}$ in 24 -well plate using per well $2.5 \mathrm{~mL}$ Dulbecco's Modified Eagle's medium containing $50 \mu \mathrm{g} / \mathrm{mL}$ of gentamycin, $2 \mathrm{mmol} / \mathrm{L}$ of L-glutamine, $1 \mathrm{mmol} / \mathrm{L}$ of sodium pyruvate, $15 \mathrm{mmol} / \mathrm{L}$ of HEPES and $10 \%$ of heat-inactivated Fetal calf serum (all from Sigma-Aldrich). Isolated splenocytes, for each group, were stimulated in vitro with His6-Ply $(0.2,5$ and $10 \mu \mathrm{g} / \mathrm{mL})$, Concanavalin A (positive control) or not stimulated (negative control). The levels of IFN- $\gamma$, IL-4, and IL$17 \mathrm{~A}$ in the supernatant of the culture were measured by double sandwich capture ELISA (Mabtech, Sweden). Results are expressed as mean \pm SD of two replicates per vaccination group at time $72 \mathrm{~h}$ corresponding to the in vitro cytokine production peak. 
Assessment of antibody recognition of Ply in various serotypes by immunoblot. The specific binding of antibodies induced by immunization with Ply-PhaC beads or soluble His6-Ply to Ply from various $S$. pneumoniae serotypes was assayed as previously described. In this study, the strains assayed were from serotypes $1,3,5,19 \mathrm{~F}, 23 \mathrm{~F}$ and $18 \mathrm{C}$. The cell suspension was adjusted to a final concentration of $10 \%(\mathrm{w} / \mathrm{v})$ and denatured by heating at 95 ${ }^{\circ} \mathrm{C}$ for $20 \mathrm{~min}$. Ten $\mu 1$ of the soluble fraction of these samples were separated by SDS-PAGE using a 10\% (w/v) acrylamide gel. Immunoblot was conducted using sera dilutions of 1: 1750 for group Ply-PhaC and 1: 500 for group His6-Ply.

Opsonophagocytosis activity assay (OPA). The OPA used was based on that described by Romero-Steiner ${ }^{56}$ but using human polymorphonuclear leukocytes as effector cells. In brief, heat-inactivated mice serum was serially diluted in two-fold steps in a 96-well microtiter plate (round bottom, COSTAR) with opsono-buffer (Hank's buffer (Sigma) containing $0.1 \%(\mathrm{w} / \mathrm{v})$ gelatin) and were incubated with cells of $S$. pneumoniae serotype $19 \mathrm{~F}$ $\left(\sim 1,000 \mathrm{CFU}\right.$ per well) for $15 \mathrm{~min}$ at $37^{\circ} \mathrm{C}$ in a $5 \% \mathrm{CO}_{2}$ atmosphere. Complement from baby rabbit serum (Pel-Freez Biological) and peripheral polymorphonuclear leukocytes purified from human blood as effector cells were added at $4 \times 10^{5}$ cell per well. The mixture was incubated at $37^{\circ} \mathrm{C}$ for 45 min with shaking ( $90 \mathrm{rpm}$ ). The reaction was stopped by cooling on ice for $5 \mathrm{~min}$. After the phagocytosis step $5 \mu \mathrm{L}$ aliquots were removed and applied onto a tilted Todd Hewitt yeast extract agar plate, and the plate was incubated at $37{ }^{\circ} \mathrm{C}$ with $5 \% \mathrm{CO}_{2}$ for $18 \mathrm{~h}$. OPA titers were calculated as the reciprocal of the serum dilution that caused a $50 \%$ reduction of the CFU (killing) compared to the CFU from the control wells containing all reagents except rabbit serum. The results are shown as the mean \pm SEM of 8 animals.

Statistical analysis. Graph Pad Prism 5.00 (San Diego, USA) software was used for statistical analysis of data. Statistical differences between all groups were calculated by oneway analysis of variance (ANOVA) with Kruskal-Wallis non-parametric test. When 
significant differences were found, the Dunn's post-test was used considering significance at $p<0.05$. When the comparison was just between two groups the Mann-Whitney test was performed and statistical differences were considered significant at $(p<0.05)$.

\section{RESULTS}

Bioengineering $E$. coli for production of Ply-PHB beads and soluble His6-Ply. Ply is one of the most conserved proteins across pathogenic S. pneumoniae strains. ${ }^{57}$ The Ply amino acid sequence was selected from S. pneumoniae strain R36A with two mutations (G293T, C428A) to remove toxicity as described elsewhere. ${ }^{36-37}$ A schematic representation of the genes encoding fusion proteins mediating PHB bead production and production of soluble His6-Ply are depicted in Figure. 1A.

To confirm the presence of PHB inclusions in E. coli harboring pET14b-ply-phaC or pET14b-phaC, the cell was subjected to TEM analysis. Additionally, in order to determine the shape and size of the PHB beads, purified bead samples were also analysed by TEM (Figure. 1B). Figures 1B.1 and 1B.2 show cells harboring either plasmid were able to produce PHB inclusions. However, after isolation and purification, beads from cells harboring pET14b-phaC (Figure. 1B.3) appeared smaller $(<500 \mathrm{~nm})$ and more homogeneously spherical than beads isolated from cells harboring pET14b-ply-phaC (Figure. 1B.4). In addition, the GC/MS analysis of the purified Ply-PhaC and PhaC wild-type beads confirmed the presence of PHB, a homopolymer made of 3-hydroxubutyrate. PHB contributed to about $85 \%$ of the beads dry weight. The surface charge of antigen-coated beads can potentially impact on immunogenicity. Hence, the Zeta potential of the PHB beads 
was determinate as a function of $\mathrm{pH}(3.5-7.5)$. Negative Zeta potentials at all measured $\mathrm{pH}$ values suggested an anionic surface charge for all beads (Table S1).

Proteins associated with PHB beads as well as His6-Ply were identified by SDS-PAGE, tryptic peptide fingerprinting and immunoblotting (Figure. 1C.1, Table 4). In Figure. 1C.1, dominant bands indicated the production of the proteins of interest, all were corresponding to their expected theoretical molecular weight. However, faint bands and smear are observed in lanes 1 and 3, possibly corresponding to higher molecular weight aggregates. The molecular identity of proteins was further confirmed by tryptic peptide mass spectrometry (Table 4). Also, immunoblotting confirmed the molecular identity of Ply as part of the PhaC fusion protein as well as its soluble counterpart (Figures. 1C. 2 and 3). A slight smear above target protein bands (Figures. 1C. 2, lane 1 and 1C. 3, lane 3) suggested aggregation, while the smear below the target protein (Fig. 1C. 3, lane 3) could be due to degradation caused by unspecific proteases. Densitometry analysis showed a purity of His6-Ply of $>95 \%$. 
1.A

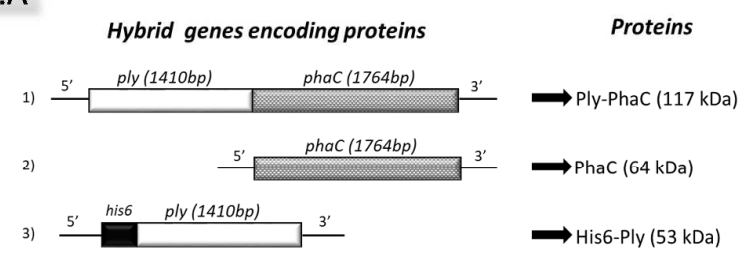

1.B

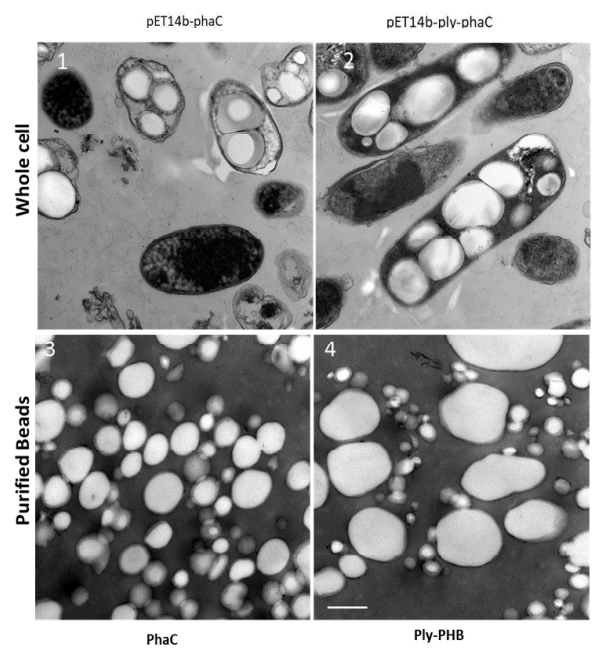

1.C

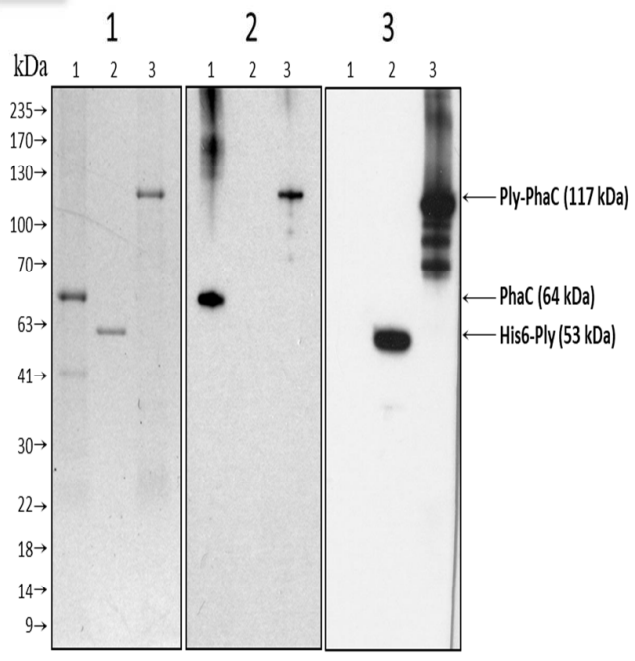

Figure 1. Design, production and characterization of the PHB beads. 1A. Schematic representation of genes encoding proteins relevant to this study. 1A.1, the hybrid gene encoding Ply-PhaC fusion protein mediating PHB bead formation; 1A.2, the gene encoding PhaC mediating non-antigen displaying PHB bead formation; 1A.3, the gene encoding a soluble His6-tagged Ply. 1B. TEM images of E. coli with PHB inclusions and the corresponding purified PHB beads. 1B.1, cells harboring pET14b-phaC (PhaC wild type, non-antigen displaying); 1B.2, cells harboring pET14b-ply-phaC (Ply-PhaC bead); 1B.3, PhaC beads from cells harboring pET14b-phaC; 1B.4, Ply-PhaC beads derived from cells harboring pET14b-ply-phaC. The white bar represents $500 \mathrm{~nm}$. 1C. SDS-PAGE and immunoblot analysis of proteins attached to PHB beads as well as purified His6-Ply. 1C.1 Coomassie blue stained SDS-PAGE gel; 1C.2 Immunoblot using polyclonal anti-PhaC antibodies; 1C.3 Immunoblot using monoclonal anti-PLY antibodies (PLY-7). Lane 1, PHB beads isolated from cells harboring pET-14b-phaC encoding PhaC, non-antigen displaying (64 kDa); lane 2, purified His6-Ply (53 kDa) derived from cells harboring pET14b-his6-ply; lane 3, PHB beads isolated from cells harboring pET-14b-ply-phaC encoding Ply-PhaC fusion protein $(117 \mathrm{kDa})$. Molecular weight $(\mathrm{MW})$ standard (GangNam-Stain, iNtRON BIOTECHNOLOGY) was used. The arrows indicate the protein bands of interest with the corresponding theoretical MW in parentheses.

Table 4. Tryptic peptide fingerprinting analysis using liquid chromatography tandem-mass spectroscopy including TripleTOF analysis 


\begin{tabular}{|l|l|}
\hline Protein & $\begin{array}{l}\text { Protein regions as identified by peptide fragment analysis } \\
\text { (TripleTOF) }\end{array}$ \\
\hline Ply-PhaC fusion protein & $\begin{array}{l}\text { A1-K353, N359-K388, A395-R428, I434-K782, G807- } \\
\text { L817, E835-G858, N876-K884, H914-Q1006, R1031- } \\
\text { R1054 }\end{array}$ \\
\hline His6-Ply & $\begin{array}{l}\text { A11-V50, V51-R100, A101-V150, P151-N200, F201- } \\
\text { R250, D251-G300, D301-F350, Q351-P400, K401-D450, } \\
\text { L451-D477 }\end{array}$ \\
\hline
\end{tabular}

Bold, identified peptides belonging to Ply.

To determine the amount $(\mu \mathrm{g})$ of Ply or PhaC per mg of wet in Ply-PhaC beads and PhaC wild type PHB beads, respectively, another SDS-PAGE including BSA standards was conducted and subjected to densitometry analysis (Figure. S1). The results are presented in

Table 5.

Table 5. PHB beads yields and the antigen/ $\mathrm{mg}$ of wet beads ratio

\begin{tabular}{|l|c|c|c|}
\hline Sample & $\begin{array}{c}\text { Wet PHB beads } \\
\text { mass } \\
(\mathrm{g})\end{array}$ & $\begin{array}{c}\text { Fraction of Ply in } \\
\text { fusion protein } \\
(\%)\end{array}$ & $\begin{array}{c}\text { protein*/wet bead } \\
(\mu \mathrm{g} / \mathrm{mg})\end{array}$ \\
\hline PhaC beads & 0.748 & 0 & 0.4 \\
\hline Ply-PhaC beads & 1.37 & 45 & $0.142(\mathrm{Ply}) / 0.173(\mathrm{PhaC})$ \\
\hline
\end{tabular}

* Protein: PhaC in case of PhaC wild type PHB beads, Ply in case of Ply-PhaC beads.

Immunological properties of the various PHB beads and soluble proteins. Safety of vaccine formulations: All animals included in the immunization schedule remained alive and healthy. Small lumps at the immunization sites with no detectable suppuration were only evident in groups immunized with PHB bead containing vaccine formulations. Additionally, organs such as lungs, liver, and kidneys showed a normal shape in all mice.

Anti-Ply IgG titers and IgG subclass profile: The IgG titers against Ply were evaluated by ELISA (Figure. 2A). All animals from Ply-PhaC beads and His6-Ply immunization groups were considered as responders showing specific and high IgG titers against Ply, seven days after the last vaccination (Figure. 2A), while PhaC beads and alum were negative. The mean IgG titers in the Ply-PhaC beads group was statistically superior to His6-Ply group with $p<$ 
0.001. Subclass Ig profiles are depicted in Figure. 2B. IgG1 was the prevalent subclass of the Ply-PhaC beads and His6-Ply groups, however, the Ply-PhaC beads group presented superior titers in comparison with the His6-Ply group with $p<0.05$. Additionally, IgG2b titers were higher in the Ply- PhaC beads when compared to the His6-Ply group with $p<0.01$.

Cross-reactivity of induced antibodies with Ply from various S. pneumoniae serotypes: To evaluate the binding specificity of antibodies of pooled sera from animals immunized with Ply-PhaC beads and soluble His6-Ply to Ply from various $S$. pneumoniae serotypes an immunoblot was performed (Figure. 2C). The results showed that in both cases, sera recognized predominantly a protein that coincided with the theoretical molecular weight of Ply. However, sera from Ply-PhaC required 3.5-fold greater dilution than sera from His6-Ply suggesting that immunization with Ply displayed on PHB beads enhanced immunogenicity toward increased induction of anti-Ply antibodies when compared with soluble Ply. 

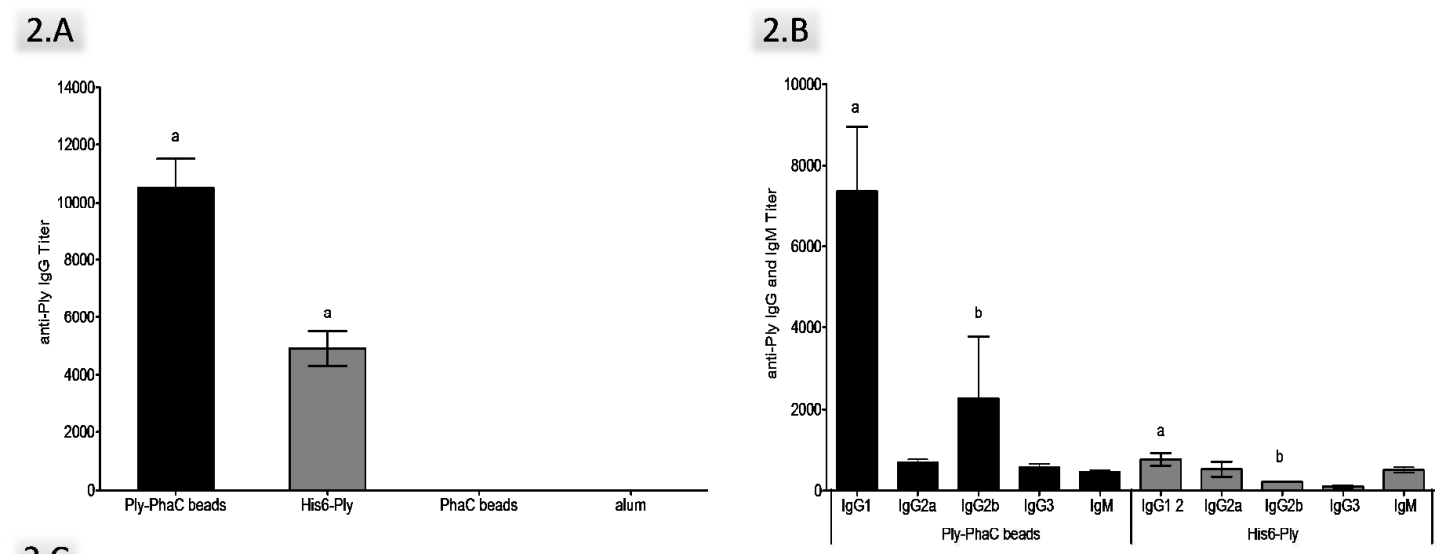

\section{C}

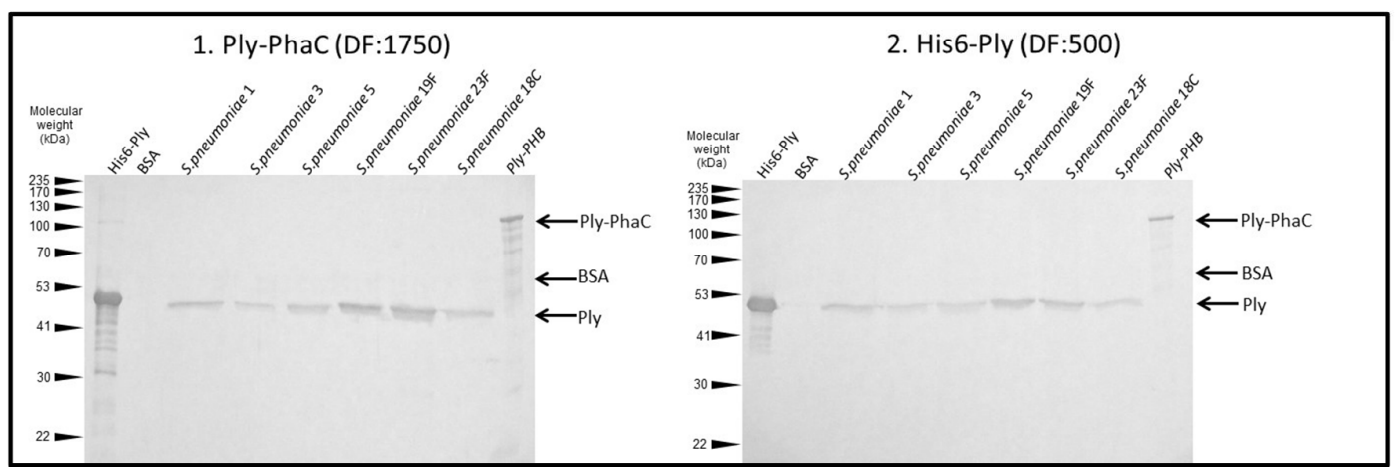

Figure 2. Humoral immune response evaluation against pneumolysin. 2A Analysis of induction of anti-Ply antibodies by various vaccine formulations. Black bar represent sera from mice immunized with $1.5 \mu \mathrm{g}$ of Ply displayed on PHB beads $+15 \mu \mathrm{g}$ of alum; grey bar represent sera from mice immunized with $1.5 \mu \mathrm{g}$ of soluble His6-Ply $+15 \mu \mathrm{g}$ of alum; black line bar represent sera from mice immunized with $1.5 \mu \mathrm{g}$ of PhaC on PHB beads $+15 \mu \mathrm{g}$ of alum (i.e. no antigen PHB bead, negative control); white bar represent mice immunized with $15 \mu \mathrm{g}$ of alum. All immunogens were isolated from an endotoxin-free mutant of $E$. coli. Statistical analysis by the Mann-Whitney test showed that Ply-PhaC beads vs His6-Ply present statistical differences with $p<0.001$. 2B Ig isotypes titers assessed by ELISA. Statistical analysis by Kruskal-Wallis non-parametric test showed: IgG1, Ply-PhaC beads group $>$ His6-Ply group; ${ }^{\mathrm{a}} p<0.05$. While IgG2b, Ply-PhaC beads group $>$ His6-Ply group; ${ }^{\mathrm{b}}$ $p<0.01$. 2C Cross-reactivity of anti-Ply antibodies with Ply from various serotypes of $S$. pneumoniae. 1, immunoblots using pooled sera (diluted 1:1750) from 8 mice immunized with Ply-PhaC beads; 2, immunoblot using pooled sera (diluted 1:500) from 8 mice immunized with soluble His6-Ply. The corresponding SDS-PAGE of whole cell lysates of the various $S$. pneumoniae serotypes is provided in Supplemental Figure. S2. Lane 1, His6-Ply (positive control), Lane 2, BSA (negative control), Lanes 3-8, Whole cell lysates from 6 different $S$. pneumoniae strains, Lane 9, Ply-PhaC beads (control).

Cellular immune responses post Ply immunization. Splenocytes from the immunized animals were stimulated with His6-Ply, results are presented in (Fig. 3). The results showed 
that splenocytes from animals immunized with Ply-PhaC beads produced high levels of IL17A and IFN- $\gamma$. However, animals immunized with soluble His6-Ply produced high levels of IFN- $\gamma$, but only low levels of IL-17A (Fig. 3). IL-4 was not detected in any of the splenocyte cultures (data not shown). Additionally, animals immunized with PhaC beads and alum showed negative results of both cytokines.
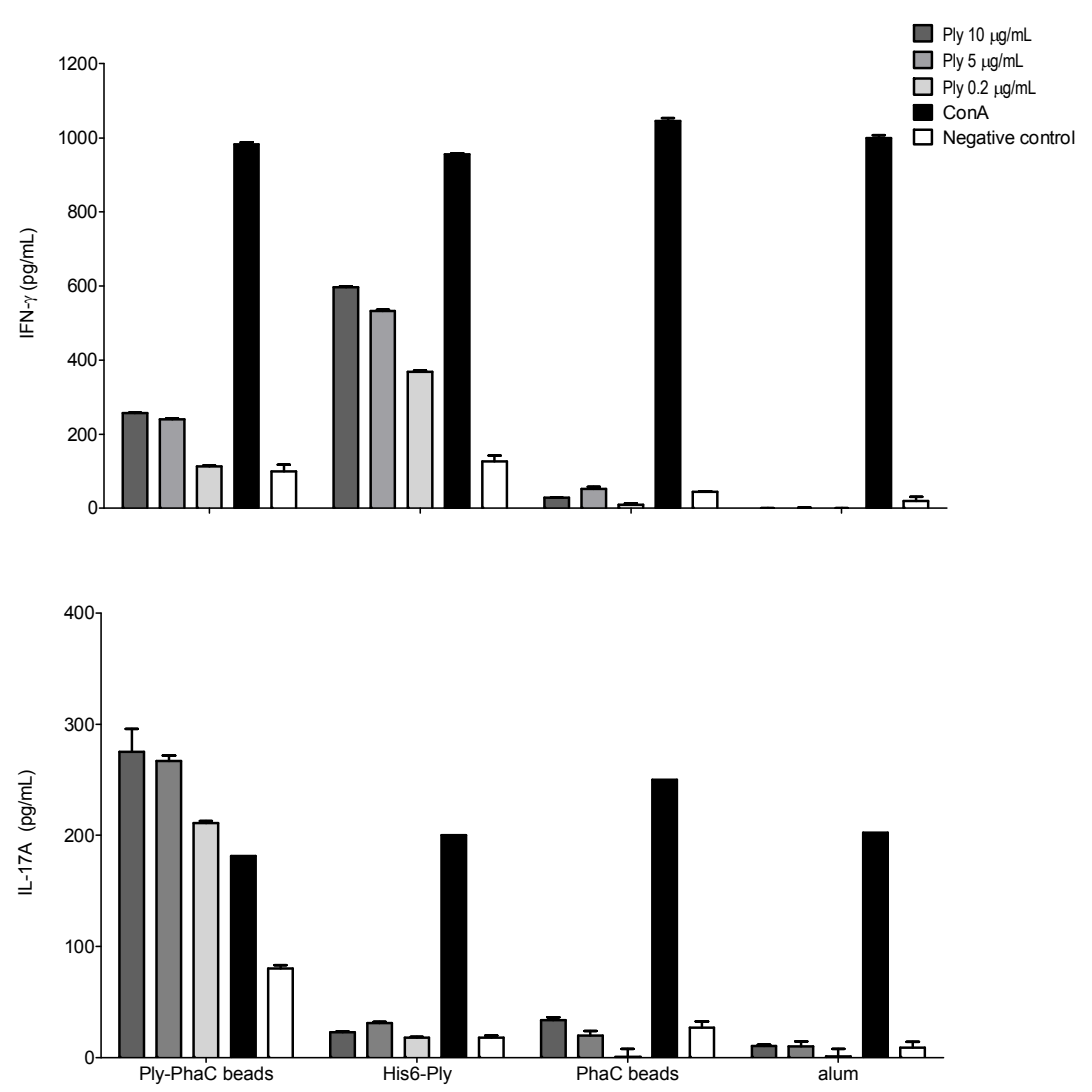

Figure 3. Cytokine profiles induced by various vaccine formulations. Splenocytes were stimulated with His6-Ply $(0.2,5$ or $10 \mu \mathrm{g} / \mathrm{mL})$ and the supernatant of splenocyte cultures was evaluated at different times $(24,48,72$ and $96 \mathrm{~h})$. The results show time $72 \mathrm{~h}$ corresponding to in vitro cytokine production peak. Splenocytes without stimulant were considered as negative controls while cells activated with ConA were considered as positive control. Results are represented as the mean $\pm \mathrm{SD}$ of two replicates per group. Data represent one experiment using the splenocytes pool from 8 animals per group. 


\section{Chemical conjugation of CPS from $S$. pneumoniae serotype $19 F$ to PHB beads. Prior} to conjugation, proteins were activated with the maleimide group specifically reacting with sulfhydryl groups resulting in yields of activation in accordance with previously described results. ${ }^{45}$ The conjugation strategy and the final beads are shown in Figure. 4A. After the conjugation reactions, the 19F-PhaC bead conjugate was washed five times to remove the unbound CPS. Then, the $19 \mathrm{~F}$ polysaccharide and protein content in the final conjugate was determined as described in Materials and Methods. The results showed that $14 \%$ of $19 \mathrm{~F}$ polysaccharide and $75 \%$ of protein were retained after conjugation. The final ratio $\mathrm{mg}$ polysaccharide: $\mathrm{mg}$ protein was $1: 2.7$.

Anti-19F IgG titer evaluation and Functionality of induced antibodies assessed by opsonophagocytosis of $S$. pneumoniae serotype 19F. The IgG titers against CPS from $S$. pneumoniae serotype $19 \mathrm{~F}$ were evaluated by ELISA. The serum from animals immunized with $19 \mathrm{~F}$ polysaccharide conjugated to PHB beads and TT were positive seven days after the last immunization dose, while mice immunized with CPS 19F mixed with PhaC beads and alum were negative. The mean IgG titer from group 19F-PhaC beads was statistically superior to group 19F-TT with $p<0.01$ (Figure. 4B).

To determine the functionality of the antibodies, an opsonophagocytic activity assay was performed. ${ }^{56}$ Animals immunized with $19 \mathrm{~F}$ conjugated to PhaC showed OPA titers greater than 512 which demonstrated strong immunogenicity of the 19F-PhaC beads. Additionally, statistical differences were found between animals immunized with 19F-PhaC beads and 19F-TT with $p<0.001$ (Figure. 4C). 


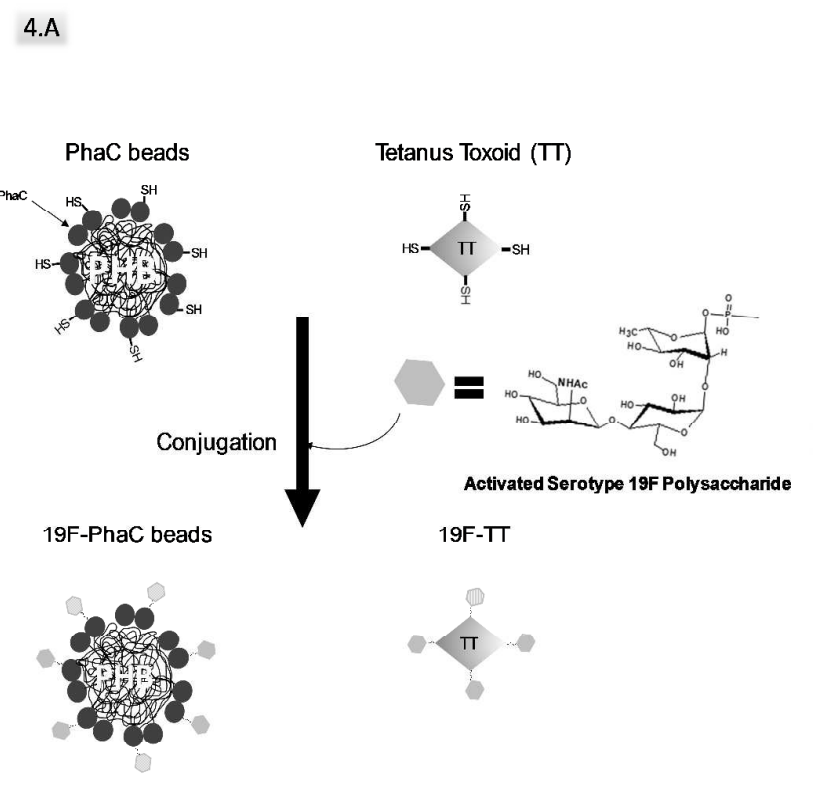

4.B

4.C
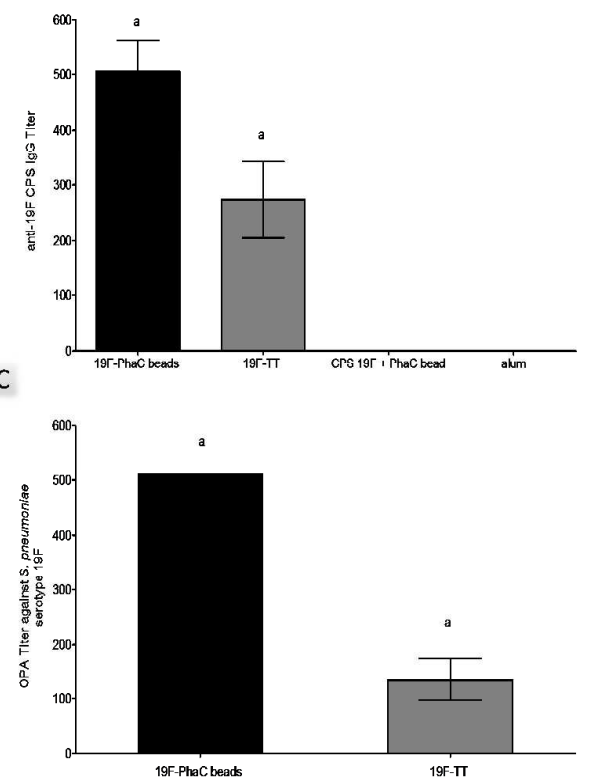

Figure 4. Design, production and immunological characterization of the conjugate PHB beads. 4A Schematic representation of conjugation reaction between activated serotype 19F polysaccharide and $\mathrm{PhaC}$ on $\mathrm{PHB}$ beads or soluble TT. The repetitive unit of the $19 \mathrm{~F}$ polysaccharide is a trisaccharide of $(\rightarrow 4)-\beta$-D-ManNAc- $(1 \rightarrow 4)-\alpha-\mathrm{D}-\mathrm{Glcp}-(1 \rightarrow 2)-\alpha-\mathrm{L}$ Rhap-1-PO4-) ${ }^{58-60}$ 4B Analysis of anti-19F CPS antibody titers. Black bar, group immunized with $2 \mu \mathrm{g}$ of $19 \mathrm{~F}$ polysaccharide conjugated to PhaC on PHB beads $+125 \mu \mathrm{g}$ of alum; grey bar, group immunized with $2 \mu \mathrm{g}$ of $19 \mathrm{~F}$ polysaccharide conjugated to TT $+125 \mu \mathrm{g}$ of alum; black line bar, group immunized with a mix of 19F CPS $(10 \mu \mathrm{g})+\mathrm{PhaC}(30 \mu \mathrm{g})+125 \mu \mathrm{g}$ of alum and white bar, group immunized with $125 \mu \mathrm{g}$ of alum. Statistical analysis using the Mann-Whitney test showed that group 19F-PhaC beads $>19 \mathrm{~F}-\mathrm{TT} .{ }^{\mathrm{a}} p<0.01$. 4C The opsonophagocytic activity of sera against $S$. pneumoniae serotype 19F. Black bar, 19F-PhaC beads group immunized with $2 \mu \mathrm{g}$ of $19 \mathrm{~F}$ polysaccharide conjugated to $\mathrm{PhaC}$ wild type beads $+125 \mu \mathrm{g}$ of alum; grey bar 19F-TT, group immunized with $2 \mu \mathrm{g}$ of $19 \mathrm{~F}$ polysaccharide conjugated to TT $+125 \mu \mathrm{g}$ of alum. The assay was performed using serum from each immunized animal/group. Statistical analysis using the Mann-Whitney test showed: group $19 \mathrm{~F}-\mathrm{PhaC}>$ group $19 \mathrm{~F}-\mathrm{TT}^{\mathrm{a}} p<0.001$.

\section{DISCUSSION}

S. pneumoniae is a human pathogen secreting virulence factors such as various CPS and proteins. More than 91 serotypes exist but only 30 were found to be disease causing. CPS protein conjugate vaccines including CPS from up to 13 serotypes are able to elicit serotype dependent protective and long-term immunity in infants. The serotype $19 \mathrm{~F}$ is part of all commercial vaccines due to its epidemiological relevance. However, the serotype dependent 
protection excludes its use against emerging virulent serotypes which CPS is not included in current vaccine formulations. Alternatively, a vaccine formulation based on conserved proteins, like Ply, could provide a different approach to induce broadly protective (serotypeindependent) immune responses overcoming limitations of existing conjugate vaccines.

Non-toxic Ply variants as part of next generation pneumococcal vaccines induced protective humoral and cellular immune responses in mice and humans. ${ }^{2,61-62}$ However, high amounts of Ply combined with adjuvants were required to achieve this protection. Here, we explored the design of PHB beads as a potential Ply delivery system and its capacity to improve the immunogenicity of this protein.

Previous studies showed that proteinaceous antigens from intracellular pathogens like Mycobacterium tuberculosis and Hepatitis C virus could be displayed on PHB beads inducing protective Th1/Th2 immune responses. ${ }^{28-29,} 63$ Particulate vaccines are inherently immunogenic often inducing both Th1 and Th2 immune responses mediating protection against pathogens. ${ }^{64}$ Hence display of Ply and the 19F CPS on PHB beads were conceived to develop a particulate vaccine for the prevention of pneumococcal infections.

Here, we engineered an endotoxin-free mutant of $E$. coli to produce Ply displaying PHB beads (Figure. 1). ${ }^{65}$ GC/MS analysis confirmed that beads were predominantly composed of PHB contributing to about $85 \%$ of their dry weight. It is not understood, why Ply-PhaC fusion proteins mediated the formation of larger granules (up to $1 \mu \mathrm{m}$ ) when compared with only PhaC (Figure. 1B. 2). However, these results combined with those from GC/MS analysis suggested that Ply fused to the $N$-terminus of PhaC did not impact PHB synthase activity but might have had an effect on the self-assembly process. It has been shown that vaccine particle size has an impact on uptake by antigen presenting cell (APC), as well as the subsequent antigen processing, often resulting in humoral or cellular immune responses. ${ }^{66-67}$ Polystyrene spheres with diameters of $0.1-1 \mu \mathrm{m}$ were preferentially taken up by dendritic 
cells (DCs). In this case, spheres of $1 \mu \mathrm{m}$ exhibiting dense positive charges were better taken up by DCs when compared with spheres showing negative surface charges. However, the uptake of spheres with a diameter of about $0.1 \mu \mathrm{m}$ by DCs was independent of the surface charge. ${ }^{68}$ Although extensively studied, the relationship between the surface charge, uptake by dendritic cells (DCs) and the immune response is still not well understood. Ply-PhaC and PhaC wild-type PHB beads showed an anionic surface charge at $\mathrm{pH} 7.5$, which corresponded with the theoretical isoelectric point and previously manufactured PHB beads (Table. S1). ${ }^{34}$ However, how this negative charge impacted in the immune response remains to be elucidated. As a prerequisite for vaccine development, the production of stable Ply and its fusion protein was confirmed (Figure. 1C; Table 4).

To study the immunological properties of Ply-PhaC beads, mice were immunized. Small lump at the immunization sites was evident in groups immunized with PHB bead. Future histopathological studies will need to be conducted to analyze these small lumps at the injection sites. IgG titer evaluation showed that animals immunized with Ply-PhaC beads produced high anti-Ply titers in comparison with controls groups (PhaC beads and alum). Similar results were presented by $\mathrm{Lu}$ and collaborator, where a detoxified Ply (Plym2) displayed on Bacterium like particles (BLP) (BLP-Plym2) promoted the production of higher IgG titers (serum) than the BLP alone. ${ }^{69}$ In addition, we found that the IgG titer from group vaccinated with Ply-PhaC beads were greater in comparison with the soluble protein suggesting that PHB beads enhanced immunogenicity as supported by previous finding (Figure. 2A) ${ }^{28}$ In a recent study, the Neisseria adhesin A (NadA) displayed on PHB beads induced a superior immune response in comparison to soluble NadA, and this was independent of the presence of alum in the formulation. This suggested self-adjuvanting properties of the PHB beads. ${ }^{34}$ In patients with pneumococcal bacteremia, anti-Ply-antibodies were present in about $60-80 \%$ of the adults suggesting the importance of the Ply-specific 
humoral immune responses for clearance of this pathogen from the human body. ${ }^{70-71}$ In a previous study vaccinations with detoxified Ply (PlyD1) showed that a dose of 5 and $10 \mu \mathrm{g}$ per animal combined with alum induced protective immunity. ${ }^{36}$ The induced antibodies also inhibited hemolytic activity of Ply and reduced lung damage in mice. In our study, IgG1 was the predominant subclass induced by Ply, which resembles previous findings using the PdB (pneumolysoid, a mutation in W433F) protein (Figure. 2B). ${ }^{2,72}$ To demonstrate that Ply-PHB beads induced serotype-independent recognition by the sera from immunized animals, an immunoblot with cell lysates of six S. pneumoniae serotypes was performed and the results showed that a molecule, with the same electrophoretic mobility as His6-Ply was specifically recognized by the pooled sera from Ply immunized animals (Figure. 2C).

A combination of humoral and cellular immunity plays a crucial protective role against S. pneumoniae infection. ${ }^{14,}{ }^{73}$ S. pneumoniae mouse infection models have shown the relevance of IL-17A and IFN-y secretion for the development of a protective immune response. $^{74-77}$ In the early infection state, the production of IL-17 mediates the recruitment of macrophage and neutrophil precursors clearing bacteria from the nasopharyngeal tissue in mice. ${ }^{78}$ In addition, several studies investigated the relevance of Ply in the cellular immunity against S. pneumoniae. A study which combined Ply with a TLR 4 agonist showed a correlation between splenocyte IL-17A, IFN-y and IL-1 $\beta$ production and protection against infection in mice. ${ }^{62}$ Another study showed that secretion of IL-17A by $\gamma \delta$ T lymphocytes mediated the differentiation of Th17 cells. ${ }^{79}$ Production of IFN-y together with IL-18 and IL12 were important to mediate a Th1 pattern differentiation. ${ }^{62}$ Here Ply displayed on PHB beads induced both IL-17A and IFN-y production (Figure. 3). Interestingly, the production of IL-17A in mice immunized with His6-Ply was very low in comparison with the group of Ply-PhaC, however, further studies should be performed to explain this observation. Immunization with Ply-PhaC beads might induce a cytokine profile which could promote 
cell-mediated protective immunity. An unexpected result was the production of high levels of IgG1 antibodies while the production of IL-4 was not detectable and IFN-y was high. However, T helper 2 cells produce not only IL-4, but also IL-10, IL-6 and IL-5 which are tightly related to antibody production and class switching. To further elucidate the mechanism on how Ply-PhaC beads induce an immune response, a wider cytokine spectrum will be evaluated in future studies. Since Ply-PhaC beads induced high and specific IgG antibodies titers, presumably able to recognize Ply regardless of the serotype, as well as induced production of cytokines such as IL17A and IFN-y, PHB beads could be considered as particulate immunogenic antigen carrier. However, further studies are needed to assess the relationship between cytokine profiles and antibody serotypes. Ultimately, challenge experiments will be needed to investigate the level of protective immunity induced by the Ply-PhaC beads which will be important towards the development of a PHB bead based vaccine.

As CPS, conjugated to immunogenic carrier proteins such as TT, had been previously successfully used in vaccine formulations against pneumococcal disease ${ }^{80}$, they were also considered in this study. CPS are poorly immunogenic by themselves in children and hence require conjugation to an immunogenic carrier protein such as TT.

Here we replaced the immunogenic carrier protein with PHB beads. This was achieved by chemical conjugation of CPS serotype 19F to purified PHB beads (Figure. 4A). ${ }^{81}$ The serotype 19F CPS was selected as a model CPS antigen in this paper due to its epidemiological prevalence worldwide. ${ }^{82}$ The CPS conjugation recovery was about $14 \%$, which was less than previously described. ${ }^{45}$ This could be due to fewer conjugation sites being accessible at the surface of the PHB beads. To evaluate the efficacy of the pneumococcal polysaccharide-protein conjugate vaccines, the total $\mathrm{IgG}$ antibody production, IgG functionality (OPA assay using homologous strain), immunological memory and 
protection in challenge studies were measured. ${ }^{83-84}$ In our study and similar to previous reports, immune response evaluation showed that $19 \mathrm{~F}-\mathrm{PhaC}$ beads promoted the production of specific and high IgG titers than the group immunzed with alum. ${ }^{54}$ Interestingly, the nonconjugated mix of 19F CPS and PHB beads did not induce detectable IgG titer, which suggested that co-delivery of antigens and PHB beads is required for induction of an immune response. ${ }^{54,85}$ In addition, IgG titer were superior when mice were vaccinated with $19 \mathrm{~F}-\mathrm{PhaC}$ than with 19F-TT, which was used as a positive control (Figure.4B).

The IgG titers induced by 19F-PhaC beads remained high up to 6 months after the last vaccination (Figure. S3) suggesting that 19F-PhaC beads induced a strong and long-lasting humoral immune response. Phagocytosis by macrophages mediated by opsonic antibodies is used to demonstrate their functionality after vaccination with pneumococcal conjugate vaccines. ${ }^{86-88}$ The greatest OPA titers were elicited after immunization with 19 F-PhaC beads (Figure. 4C), which demonstrated induction of functional antibodies. These results suggested that PHB beads can also serve as an immunogenic carrier for the delivery of carbohydratebased antigens towards the design of efficient particulate vaccines.

\section{- CONCLUSIONS}

Here we showed that PHB inclusions can be engineered to display the pneumoccocal antigen, pneumolysine, to serve as particulate vaccine. Pneumolysine displaying PHB particles induced a strong and specific humoral responses, which associated antibodies bound to pneumolysine from various serotypes of $S$. pneumoniae suggesting the induction of broadly protective immunity. These PHB particles also induced a strong Th17 response considered to play an important role for clearance of lung infections. We also demonstrated that PHB particles can serve as immunogenic carrier for capsular polysaccharides. Capsular polysaccharides were chemically conjugated to PHB particles and respective particles induced a opsonophagocytitic antibody titers when compared to tetanus toxoid as 
immunogenic carrier. Overall, this study revealed that pneumococcal proteinaceous and carbohydrate antigens can be efficietly displayed on PHB beads exhibiting superior immunological properties laying the foundation for the design and development of a new multivalent particulate vaccine preventing infection by $S$. pneumoniae.

\section{AUTHORS INFORMATION}

\section{Corresponding Author}

*E-mail: b.rehm@griffith.edu.au. Tel: +61737354233

\section{Notes}

The authors declare the following competing financial interest(s): B.H.A.R. is co-founder and shareholder of PolyBatics Ltd that commercializes veterinary TB diagnostic products related to the polyester bead technology.

\section{ACKNOWLEDGEMENTS}

This study was funded by the MacDiarmid Institute of Nanotechnology and Advanced Materials (New Zealand), Finlay Vaccine Institute (Cuba), Massey University (New Zealand) and Griffith University (Australia). The authors are also thankful to Dr Anja Werno (Canterbury Health Laboratories, New Zealand) for the provision of anti-Ply monoclonal antibodies. The technical assistance by María Onelia González Socarras, Alex QuinteroPerez, Dr Yanely Tirado, Dr Reinaldo Oliva Hernández, Tamara Hernández Salazar, SandraMadariaga, Yanet Estrada, Maryle García, Elizabeth González Aznar, Rocmira Perez Nicado, Danaydis Fonseca, Abel Roscoe Fajardo Sánchez and Natalie Burr. We would also like to acknowledge the Manawatu Microscopy and Imaging Centre for assistance with electron 
microscopy analysis. The authors would like to acknowledge support from the Massey University Doctoral Research Dissemination Grant 2017.

\section{ASSOCIATED CONTENT}

\section{Supporting Information}

Supporting information is available free charge on the ACS Publications website at DOI:

Supplementary Table Zeta potential evaluation, Supplementary Figures show: Quantitative SDS-PAGE to determine the amount of pneumococcal antigen per mg of wet beads, SDSPAGE of whole cell lysates of the various S. pneumoniae serotypes used to evaluate crossreactivity of induced antibodies with Ply from various $S$. pneumoniae serotypes and analysis of anti-19F CPS antibody titers, 6 months after the last immunization.

\section{REFERENCES}

1. O'Brien, K. L.; Wolfson, L. J.; Watt, J. P.; Henkle, E.; Deloria-Knoll, M.; McCall, N.; Lee, E.; Mulholland, K.; Levine, O. S.; Cherian, T.; Hib; Pneumococcal Global Burden of Disease Study, T., Burden of disease caused by Streptococcus pneumoniae in children younger than 5 years: global estimates. Lancet 2009, 374 (9693), 893-902. DOI: 10.1016/S0140-6736(09)61204-6.

2. Palaniappan, R.; Singh, S.; Singh, U. P.; Sakthivel, S. K. K.; Ades, E. W.; Briles, D. E.; Hollingshead, S. K.; Paton, J. C.; Sampson, J. S.; Lillard, J. W., Differential PsaA-, PspA, PspC-, and PdB-specific immune responses in a mouse model of pneumococcal carriage. Infect. Immun. 2005, 73 (2), 1006-1013. DOI: 10.1128/IAI.73.2.1006-1013.2005.

3. Lee, L. H.; Gu, X. X.; Nahm, M. H., Towards New Broader Spectrum Pneumococcal Vaccines: The Future of Pneumococcal Disease Prevention. Vaccines (Basel) 2014, 2 (1), 112-28. DOI: 10.3390/vaccines2010112. 
4. van der Poll, T.; Opal, S. M., Pathogenesis, treatment, and prevention of pneumococcal pneumonia. Lancet 2009, 374 (9700), 1543-56. DOI: 10.1016/S01406736(09)61114-4.

5. Black, S.; Shinefield, H.; Fireman, B.; Lewis, E.; Ray, P.; Hansen, J. R.; Elvin, L.; Ensor, K. M.; Hackell, J.; Siber, G., Efficacy, safety and immunogenicity of heptavalent pneumococcal conjugate vaccine in children. Pediatr Infect Dis J 2000, 19 (3), 187-195. 6. O'Brien, K. L.; Swift, A. J.; Winkelstein, J. A.; Santosham, M.; Stover, B.; Luddy, R.; Gootenberg, J. E.; Nold, J. T.; Eskenazi, A.; Snader, S. J., Safety and immunogenicity of heptavalent pneumococcal vaccine conjugated to CRM197 among infants with sickle cell disease. Pediatrics 2000, 106 (5), 965-972. DOI: 10.1542/peds.106.5.965.

7. Darrieux, M.; Goulart, C.; Briles, D.; Leite, L. C., Current status and perspectives on protein-based pneumococcal vaccines. Crit Rev Microbiol 2015, 41 (2), 190-200. DOI: 10.3109/1040841X.2013.813902.

8. Gor, D. O.; Ding, X.; Briles, D. E.; Jacobs, M. R.; Greenspan, N. S., Relationship between surface accessibility for PpmA, PsaA, and PspA and antibody-mediated immunity to systemic infection by Streptococcus pneumoniae. Infect. Immun. 2005, 73 (3), 1304-12. DOI: 10.1128/IAI.73.3.1304-1312.2005.

9. Nabors, G. S.; Braun, P. A.; Herrmann, D. J.; Heise, M. L.; Pyle, D. J.; Gravenstein, S.; Schilling, M.; Ferguson, L. M.; Hollingshead, S. K.; Briles, D. E.; Becker, R. S., Immunization of healthy adults with a single recombinant pneumococcal surface protein A (PspA) variant stimulates broadly cross-reactive antibodies to heterologous PspA molecules. Vaccine 2000, 18 (17), 1743-54. DOI: 10.1016/S0264-410X(99)00530-7.

10. Paton, J. C.; Andrew, P. W.; Boulnois, G. J.; Mitchell, T. J., Molecular analysis of the pathogenicity of Streptococcus pneumoniae: the role of pneumococcal proteins. Annu. Rev. Microbiol. 1993, 47 (1), 89-115. DOI: 10.1146/annurev.mi.47.100193.000513. 
11. Kadioglu, A.; Taylor, S.; Iannelli, F.; Pozzi, G.; Mitchell, T. J.; Andrew, P. W., Upper and lower respiratory tract infection by Streptococcus pneumoniae is affected by pneumolysin deficiency and differences in capsule type. Infect. Immun. 2002, 70 (6), 28862890. DOI: $10.1128 /$ iai.70.6.2886-2890.2002

12. Rubins, J. B.; Charboneau, D.; Paton, J. C.; Mitchell, T. J.; Andrew, P. W.; Janoff, E. N., Dual function of pneumolysin in the early pathogenesis of murine pneumococcal pneumonia. J Clin Invest 1995, 95 (1), 142. DOI: 10.1172/jci117631

13. Heuck, A. P.; Tweten, R. K.; Johnson, A. E., Assembly and topography of the prepore complex in cholesterol-dependent cytolysins. J Biol Chem 2003, 278 (33), 31218-31225.

DOI: 10.1074/jbc.M303151200.

14. Kadioglu, A.; Gingles, N. A.; Grattan, K.; Kerr, A.; Mitchell, T. J.; Andrew, P. W., Host cellular immune response to pneumococcal lung infection in mice. Infection and immunity 2000, 68 (2), 492-501.

15. Boulnois, G.; Paton, J.; Mitchell, T.; Andrew, P., Structure and function of pneumolysin, the multifunctional, thiol $\square$ activated toxin of Streptococcus pneumoniae. Mol Microbiol 1991, 5 (11), 2611-2616. DOI: doi.org/10.1111/j.1365-2958.1991.tb01969.x 16. O’Hagan, D. T.; Singh, M., Microparticles as vaccine adjuvants and delivery systems. Expert Rev. Vaccines 2003, 2 (2), 269-283. DOI: 10.1002/3527601449.ch8

17. Kim, M.-G.; Park, J. Y.; Shon, Y.; Kim, G.; Shim, G.; Oh, Y.-K., Nanotechnology and vaccine development. Asian J. Pharm. Sci. 2014, 9 (5), 227-235. DOI: 10.1016/j.ajps.2014.06.002.

18. Singh, M.; Chakrapani, A.; O’Hagan, D., Nanoparticles and microparticles as vaccine-delivery systems. Expert Rev. Vaccines 2007, 6 (Expert Rev. Vaccines), 797-808. DOI: $10.1586 / 14760584.6 .5 .797$. 
19. Tao Liang, M.; Davies, N. M.; Blanchfield, J. T.; Toth, I., Particulate systems as adjuvants and carriers for peptide and protein antigens. Curr. Drug Delivery 2006, 3 (4), 379388. DOI: $10.2174 / 156720106778559029$.

20. Oyewumi, M. O.; Kumar, A.; Cui, Z., Nano-microparticles as immune adjuvants: correlating particle sizes and the resultant immune responses. Expert Rev. Vaccines 2010, 9 (9), 1095-1107. DOI: 10.1586/erv.10.89.

21. Xu, J. H.; Dai, W. J.; Chen, B.; Fan, X. Y., Mucosal immunization with PsaA protein, using chitosan as a delivery system, increases protection against acute otitis media and invasive infection by Streptococcus pneumoniae. Scand. J. Immunol. 2015, 81 (3), 177-185.

DOI: $10.1111 /$ sji.12267

22. Parlane, N. A.; Grage, K.; Mifune, J.; Basaraba, R. J.; Wedlock, D. N.; Rehm, B. H.; Buddle, B. M., Vaccines displaying mycobacterial proteins on biopolyester beads stimulate cellular immunity and induce protection against tuberculosis. Clin. Vaccine Immunol. 2012, 19 (1), 37-44. DOI: 10.1128/CVI.05505-11.

23. Rehm, B. H., Bacterial polymers: biosynthesis, modifications and applications. Nat. Rev. Microbiol. 2010, 8 (8), 578-92. DOI: 10.1038/nrmicro2354.

24. Lee, S. Y.; Lee, K. M.; Chan, H. N.; Steinbuchel, A., Comparison of recombinant Escherichia coli strains for synthesis and accumulation of poly-(3-hydroxybutyric acid) and morphological changes. Biotechnol. Bioeng. 1994, 44 (11), 1337-47. DOI: 10.1002/bit.260441110.

25. Rehm, B. H., Biogenesis of microbial polyhydroxyalkanoate granules: a platform technology for the production of tailor-made bioparticles. Curr. Issues Mol. Biol. 2007, 9 (1), 41-62. DOI: 10.21775/cimb.009.041

26. Draper, J. L.; Rehm, B. H., Engineering bacteria to manufacture functionalized polyester beads. Bioengineered 2012, 3 (4), 203-8. DOI: 10.4161/bioe.19567. 
27. Hooks, D. O.; Blatchford, P. A.; Rehm, B. H., Bioengineering of bacterial polymer inclusions catalyzing the synthesis of $\mathrm{N}$-acetylneuraminic acid. Appl Environ Microbiol 2013, 79 (9), 3116-21. DOI: 10.1128/AEM.03947-12.

28. Martinez-Donato, G.; Piniella, B.; Aguilar, D.; Olivera, S.; Perez, A.; Castanedo, Y.; Alvarez-Lajonchere, L.; Duenas-Carrera, S.; Lee, J. W.; Burr, N.; Gonzalez-Miro, M.; Rehm, B. H., Protective T Cell and Antibody Immune Responses against Hepatitis C Virus Achieved Using a Biopolyester-Bead-Based Vaccine Delivery System. Clin Vaccine Immunol. 2016, 23 (4), 370-8. DOI: 10.1128/CVI.00687-15.

29. Parlane, N. A.; Rehm, B. H.; Wedlock, D. N.; Buddle, B. M., Novel particulate vaccines utilizing polyester nanoparticles (bio-beads) for protection against Mycobacterium bovis infection - a review. Vet. Immunol. Immunopathol. 2014, 158 (1-2), 8-13. DOI: 10.1016/j.vetimm.2013.04.002.

30. Parlane, N. A.; Wedlock, D. N.; Buddle, B. M.; Rehm, B. H., Bacterial polyester inclusions engineered to display vaccine candidate antigens for use as a novel class of safe and efficient vaccine delivery agents. Appl. Environ. Microbiol. 2009, 75 (24), 7739-44. DOI:

\subsection{8/AEM.01965-09.}

31. González-Miro, M.; Rodríguez-Noda, L.; Fariñas-Medina, M.; García-Rivera, D.; Vérez-Bencomo, V.; Rehm, B. H., Self-assembled particulate PsaA as vaccine against Streptococcus pneumoniae infection. Heliyon 2017, 3 (4), e00291. DOI: 10.1016/j.heliyon.2017.e00291. .

32. Parlane, N. A.; Gupta, S. K.; Rubio Reyes, P.; Chen, S.; González Miró, M.;

Wedlock, D. N.; Rehm, B. H., Self-assembled protein-coated polyhydroxyalkanoate beads: properties and biomedical applications. ACS Biomaterials Science \& Engineering 2016, (ACS Biomater. Sci. Eng.). DOI: 10.1021/acsbiomaterials.6b00355. 
33. Lee, J. W.; Parlane, N. A.; Wedlock, D. N.; Rehm, B. H., Bioengineering a bacterial pathogen to assemble its own particulate vaccine capable of inducing cellular immunity. Sci Rep 2017, 7, 41607. DOI: 10.1038/srep41607.

34. González-Miró, M.; Rodríguez-Noda, L. M.; Fariñas-Medina, M.; Cedré-Marrero, B.; Madariaga-Zarza, S.; Zayas-Vignier, C.; Hernández-Cedeño, M.; Kleffmann, T.; GarcíaRivera, D.; Vérez-Bencomo, V., Bioengineered polyester beads co-displaying protein and carbohydrate-based antigens induce protective immunity against bacterial infection. Sci Rep 2018, 8 (1), 1888. DOI: $10.1038 / \mathrm{s} 41598-018-20205-7$.

35. Grage, K.; Rehm, B. H., In vivo production of scFv-displaying biopolymer beads using a self-assembly-promoting fusion partner. Bioconjug Chem 2008, 19 (1), 254-62. DOI: $10.1021 / \mathrm{bc} 7003473$.

36. Salha, D.; Szeto, J.; Myers, L.; Claus, C.; Sheung, A.; Tang, M.; Ljutic, B.; Hanwell, D.; Ogilvie, K.; Ming, M., Neutralizing antibodies elicited by a novel detoxified pneumolysin derivative, PlyD1, provide protection against both pneumococcal infection and lung injury. Infection and immunity 2012, 80 (6), 2212-2220.

37. Oloo, E. O.; Yethon, J. A.; Ochs, M. M.; Carpick, B.; Oomen, R., Structure-guided antigen engineering yields pneumolysin mutants suitable for vaccination against pneumococcal disease. Journal of Biological Chemistry 2011, 286 (14), 12133-12140.

38. Peters, V.; Rehm, B. H., In vivo monitoring of PHA granule formation using GFPlabeled PHA synthases. FEMS Microbiol. Lett. 2005, 248 (1), 93-100. DOI:

10.1016/j.femsle.2005.05.027.

39. Amara, A. A.; Rehm, B. H., Replacement of the catalytic nucleophile cysteine-296 by serine in class II polyhydroxyalkanoate synthase from Pseudomonas aeruginosa-mediated synthesis of a new polyester: identification of catalytic residues. Biochememical Journal 2003, 374 (Pt 2), 413-21. DOI: 10.1042/BJ20030431. 
40. Thompson, T.; Rehm, B. H.; Herbert, A. B.; Saravolac, E. G. Compositions for separation methods. WO/2012/077080, 2012.

41. Thompson, T.; Rehm, B. H. A.; Herbert, A. B.; Saravolac, E. G.; McDermott, P. B.; Draper, J. L. . Compositions for separation methods. WO 2013/190453 A2, 2013.

42. Hay, I. D.; Hooks, D. O.; Rehm, B. H., Use of bacterial polyhydroxyalkanoates in protein display technologies. In Hydrocarbon and lipid microbiology protocols, Springer: 2014; pp 71-86. DOI: 10.1007/8623_2014_34

43. Scientific, T., Pierce BCA protein assay kit. Pierce BCA 449 Protein Assay Kit, 2013. 44. Organization, W. H., Recommendations to assure the quality, safety and efficacy of pneumococcal conjugate vaccines. WHO technical report series 2009, (927).

45. Fernández-Santana, V.; Cardoso, F.; Rodriguez, A.; Carmenate, T.; Peña, L.; Valdés, Y.; Hardy, E.; Mawas, F.; Heynngnezz, L.; Rodríguez, M. C., Antigenicity and immunogenicity of a synthetic oligosaccharide-protein conjugate vaccine against Haemophilus influenzae type b. Infect. Immun. 2004, 72 (12), 7115-7123. DOI: 10.1128/IAI.72.12.7115-7123.2004.

46. Lowry, O. H.; Rosebrough, N. J.; Farr, A. L.; Randall, R. J., Protein measurement with the Folin phenol reagent. The Journal and Biological Chemistry 1951, 193 (1), 265-275. 47. DuBois, M.; Gilles, K. A.; Hamilton, J. K.; Rebers, P. t.; Smith, F., Colorimetric method for determination of sugars and related substances. Anal Chem 1956, 28 (3), 350-356. DOI: $10.1021 / \mathrm{ac} 60111 \mathrm{a} 017$

48. Brandl, H.; Gross, R. A.; Lenz, R. W.; Fuller, R. C., Pseudomonas oleovorans as a source of poly ( $\beta$-hydroxyalkanoates) for potential applications as biodegradable polyesters. Appl. Environ. Microbiol. 1988, 54 (8), 1977-1982.

49. Larentis, A. L.; Argondizzo, A. P.; Esteves Gdos, S.; Jessouron, E.; Galler, R.; Medeiros, M. A., Cloning and optimization of induction conditions for mature PsaA 
(pneumococcal surface adhesin A) expression in Escherichia coli and recombinant protein stability during long-term storage. Protein Expr Purif 2011, 78 (1), 38-47. DOI:

10.1016/j.pep.2011.02.013.

50. Sambrook, J.; Fritsch, E.; Maniatis, T., Molecular Cloning: A Laboratory Reference Manual. Cold Spring Harbor Lab. Press, Plainview, NY: 1989.

51. Andrews, G. L.; Simons, B. L.; Young, J. B.; Hawkridge, A. M.; Muddiman, D. C., Performance characteristics of a new hybrid quadrupole time-of-flight tandem mass spectrometer (TripleTOF 5600). Anal Chem 2011, 83 (13), 5442-5446. DOI: doi.org/10.1021/ac200812d

52. de los Toyos, J. R.; Méndez, F. J.; Aparicio, J. F.; Vazquez, F.; Suárez, M. d. M. G.; Fleites, A.; Hardisson, C.; Morgan, P. J.; Andrew, P. W.; Mitchell, T. J., Functional analysis of pneumolysin by use of monoclonal antibodies. Infection and immunity 1996, 64 (2), 480484.

53. Werno, A. M. Development of improved diagnostic testing methods for invasive pneumococcal disease. $\mathrm{PhD}$ thesis, University of Otago, 2013.

54. McCool, T. L.; Harding, C. V.; Greenspan, N. S.; Schreiber, J. R., B-and T-cell immune responses to pneumococcal conjugate vaccines: divergence between carrier-and polysaccharide-specific immunogenicity. Infect. Immun. 1999, 67 (9), 4862-4869.

55. Merrill, W. W.; Naegel, G. P.; Matthay, R. A.; Reynolds, H. Y., Alveolar macrophage-derived chemotactic factor: kinetics of in vitro production and partial characterization. $J$ Clin Invest 1980, 65 (2), 268-76. DOI: 10.1172/JCI109668.

56. Romero-Steiner, S.; Libutti, D.; Pais, L. B.; Dykes, J.; Anderson, P.; Whitin, J. C.; Keyserling, H. L.; Carlone, G. M., Standardization of an opsonophagocytic assay for the measurement of functional antibody activity against Streptococcus pneumoniae using differentiated HL-60 cells. Clin. Diagn. Lab. Immunol. 1997, 4 (4), 415-422. 
57. Boulnois, G. J., Pneumococcal proteins and the pathogenesis of disease caused by Streptococcus pneumoniae. J. Gen. Microbiol. 1992, 138 (2), 249-259. DOI:

$10.1099 / 00221287-138-2-249$

58. Miyazaki, T.; Yadomae, T., Polysaccharides of type XIX Pneumococcus: Part II. the type specific polysaccharide and its chemical behaviour. Carbohydr. Res. 1971, 16 (1), 153159. DOI: 10.1016/s0008-6215(00)86108-x.

59. Yadomae, T.; Ohno, N.; Miyazaki, T., On the phosphate linkages and the structure of a disaccharide unit of the type-specific polysaccharide of Pneumococcus type XIX.

Carbohydr. Res. 1979, 75, 191-198. DOI: 10.1016/S0008-6215(00)84638-8.

60. Jennings, H. J.; Rosell, K.-G.; Carlo, D. J., Structural determination of the capsular polysaccharide of Streptococcus pneumoniae type-19 (19F). Can. J. Chem. 1980, 58 (11), 1069-1074. DOI: 10.1139/v80-167

61. Virolainen, A.; Jero, J.; Käyhty, H.; Karma, P.; Eskola, J.; Leinonen, M., Nasopharyngeal antibodies to pneumococcal pneumolysin in children with acute otitis media. Clin. Diagn. Lab. Immunol. 1995, 2 (6), 704-707.

62. McNeela, E. A.; Burke, Á.; Neill, D. R.; Baxter, C.; Fernandes, V. E.; Ferreira, D.; Smeaton, S.; El-Rachkidy, R.; McLoughlin, R. M.; Mori, A., Pneumolysin activates the NLRP3 inflammasome and promotes proinflammatory cytokines independently of TLR4. PLoS Pathog. 2010, 6 (11), e1001191. DOI: 10.1371/journal.ppat.1001191

63. Grage, K.; Jahns, A. C.; Parlane, N.; Palanisamy, R.; Rasiah, I. A.; Atwood, J. A.; Rehm, B. H., Bacterial polyhydroxyalkanoate granules: biogenesis, structure, and potential use as nano-/micro-beads in biotechnological and biomedical applications.

Biomacromolecules 2009, 10 (4), 660-9. DOI: 10.1021/bm801394s.

64. Rehm, B. H., Bioengineering towards self-assembly of particulate vaccines. Curr. Opin. Biotechnol. 2017, 48, 42-53. DOI: 10.1016/j.copbio.2017.03.018 
65. Mamat, U.; Wilke, K.; Bramhill, D.; Schromm, A. B.; Lindner, B.; Kohl, T. A.; Corchero, J. L.; Villaverde, A.; Schaffer, L.; Head, S. R., Detoxifying Escherichia coli for endotoxin-free production of recombinant proteins. Microb Cell Fact. 2015, 14 (1), 57. DOI: 10.1186/s12934-015-0241-5.

66. Fifis, T.; Gamvrellis, A.; Crimeen-Irwin, B.; Pietersz, G. A.; Li, J.; Mottram, P. L.; McKenzie, I. F.; Plebanski, M., Size-dependent immunogenicity: therapeutic and protective properties of nano-vaccines against tumors. J. Immunol. 2004, 173 (5), 3148-3154. DOI: doi.org/10.4049/jimmunol.173.5.3148

67. Kanchan, V.; Panda, A. K., Interactions of antigen-loaded polylactide particles with macrophages and their correlation with the immune response. Biomaterials 2007, 28 (35), 5344-5357. DOI: doi.org/10.1016/j.biomaterials.2007.08.015

68. Foged, C.; Brodin, B.; Frokjaer, S.; Sundblad, A., Particle size and surface charge affect particle uptake by human dendritic cells in an in vitro model. Int. J. Pharm. 2005, 298 (2), 315-322. DOI: 10.1016/j.ijpharm.2005.03.035.

69. Lu, J.; Hou, H.; Wang, D.; Leenhouts, K.; van Roosmalen, M. L.; Sun, T.; Gu, T.; Song, Y.; Jiang, C.; Kong, W., Systemic and mucosal immune responses elicited by intranasal immunization with a pneumococcal bacterium-like particle-based vaccine displaying pneumolysin mutant Plym2. Immunol. Lett. 2017, 187, 41-46. DOI: 0.1016/j.imlet.2017.05.003.

70. Kanclerski, K.; Blomquist, S.; Granström, M.; Möllby, R., Serum antibodies to pneumolysin in patients with pneumonia. J Clin Microbiol. 1988, 26 (1), 96-100.

71. Leinonen, M.; Syrjälä, H.; Jalonen, E.; Kujala, P.; Herva, E., Demonstration of pneumolysin antibodies in circulating immune complexes - a new diagnostic method for pneumococcal pneumonia. Serodiagnosis and immunotherapy in infectious disease 1990, 4 (6), 451-458. DOI: 10.1016/0888-0786(90)90058-v 
72. Ogunniyi, A. D.; Grabowicz, M.; Briles, D. E.; Cook, J.; Paton, J. C., Development of a vaccine against invasive pneumococcal disease based on combinations of virulence proteins of Streptococcus pneumoniae. Infect. Immun. 2007, 75 (1), 350-357. DOI:

10.1128/IAI.01103-06.

73. Kadioglu, A.; Coward, W.; Colston, M. J.; Hewitt, C. R.; Andrew, P. W., CD4-Tlymphocyte interactions with pneumolysin and pneumococci suggest a crucial protective role in the host response to pneumococcal infection. Infect. Immun. 2004, 72 (5), 2689-2697. DOI: doi: 10.1128/IAI.72.5.2689-2697.2004.

74. Rubins, J. B.; Pomeroy, C., Role of gamma interferon in the pathogenesis of bacteremic pneumococcal pneumonia. Infect. Immun. 1997, 65 (7), 2975-2977.

75. Nakamatsu, M.; Yamamoto, N.; Hatta, M.; Nakasone, C.; Kinjo, T.; Miyagi, K.; Uezu, K.; Nakamura, K.; Nakayama, T.; Taniguchi, M., Role of interferon- $\gamma$ in Va14+ natural killer T cell-mediated host defense against Streptococcus pneumoniae infection in murine lungs. Microbes Infect. 2007, 9 (3), 364-374. DOI: 10.1016/j.micinf.2006.12.003. 76. Moffitt, K. L.; Gierahn, T. M.; Lu, Y.-j.; Gouveia, P.; Alderson, M.; Flechtner, J. B.; Higgins, D. E.; Malley, R., TH17-based vaccine design for prevention of Streptococcus pneumoniae colonization. Cell Host Microbe 2011, 9 (2), 158-165. DOI: 10.1016/j.chom.2011.01.007.

77. Malley, R.; Anderson, P. W., Serotype-independent pneumococcal experimental vaccines that induce cellular as well as humoral immunity. Proc. Natl. Acad. Sci. 2012, 109 (10), 3623-3627. DOI: 10.1073/pnas.1121383109.

78. Zhang, Z.; Clarke, T. B.; Weiser, J. N., Cellular effectors mediating Th17-dependent clearance of pneumococcal colonization in mice. J Clin Invest 2009, 119 (7), 1899-1909.

DOI: $10.1172 / \mathrm{JCI} 36731$. 
79. Sutton, C. E.; Lalor, S. J.; Sweeney, C. M.; Brereton, C. F.; Lavelle, E. C.; Mills, K. H., Interleukin-1 and IL-23 induce innate IL-17 production from $\gamma \delta$ T cells, amplifying Th17 responses and autoimmunity. Immunity 2009, 31 (2), 331-341. DOI:

10.1016/j.immuni.2009.08.001.

80. González, N.; Paredes, B.; Pérez, S.; Mirabal, M.; Rivero, I.; González, C. A.; Díaz, A.; García, D.; Rodríguez, L.; Pérez, A., Safety and immunogenicity of Cuban antipneumococcal conjugate vaccine PCV7-TT in healthy adults. MEDICC rev 2015, 17, 3237.

81. Jones, C., Vaccines based on the cell surface carbohydrates of pathogenic bacteria. An. Acad. Bras. Cienc. 2005, 77 (2), 293-324. DOI: /S0001-37652005000200009.

82. Hausdorff, W. P.; Feikin, D. R.; Klugman, K. P., Epidemiological differences among pneumococcal serotypes. Lancet Infect Dis 2005, 5 (2), 83-93. DOI: 10.1016/S14733099(05)01280-6.

83. Lee, L. H.; Frasch, C. E.; Falk, L. A.; Klein, D. L.; Deal, C. D., Correlates of immunity for pneumococcal conjugate vaccines. Vaccine 2003, 21 (17), 2190-2196. DOI: $10.1016 / \mathrm{s} 0264-410 x(03) 00025-2$

84. Skinner, J. M.; Indrawati, L.; Cannon, J.; Blue, J.; Winters, M.; MacNair, J.; Pujar, N.; Manger, W.; Zhang, Y.; Antonello, J., Pre-clinical evaluation of a 15-valent pneumococcal conjugate vaccine (PCV15-CRM197) in an infant-rhesus monkey immunogenicity model. Vaccine 2011, 29 (48), 8870-8876. DOI:

10.1016/j.vaccine.2011.09.078.

85. D'Souza, B.; Shastri, P. N.; Hammons, G.; Kim, E.; Kolluru, P. L.; Carlone, G. M.; D\&rsquo;Souza, G. R. a. M. J., Immune-potentiation of Pneumococcal Capsular Polysaccharide Antigen using Albumin Microparticles. J Pharmacovigil 2018. DOI: $10.4172 / 2329-6887.1000261$. 
86. Väkeväinen, M.; Jansen, W.; Saeland, E.; Jonsdottir, I.; Snippe, H.; Verheul, A.; Käyhty, H., Are the opsonophagocytic activities of antibodies in infant sera measured by different pneumococcal phagocytosis assays comparable? Clin. Diagn. Lab. Immunol. 2001, 8 (2), 363-369. DOI: 10.1128/cdli.8.2.363-369.200.

87. Organization, W. H., Recommendations for the production and control of pneumococcal conjugate vaccines. WHO technical report series 2005, 927, 64-98.

88. Plikaytis, B. D.; Goldblatt, D.; Frasch, C. E.; Blondeau, C.; Bybel, M. J.; Giebink, G. S.; Jonsdottir, I.; Käyhty, H.; Konradsen, H. B.; Madore, D. V., An analytical model applied to a multicenter pneumococcal enzyme-linked immunosorbent assay study. J. Clin.

Microbiol. 2000, 38 (6), 2043-2050. 


\section{A}

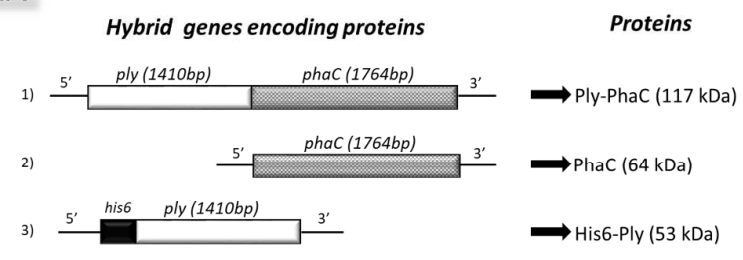

1.B

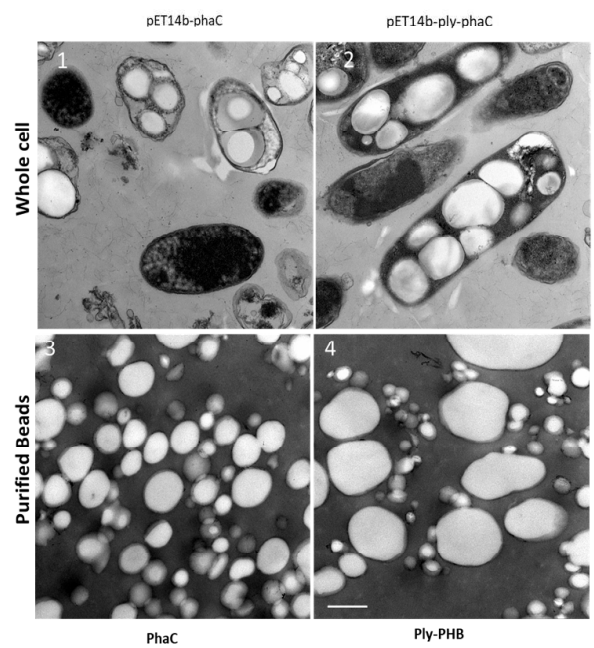

1.C

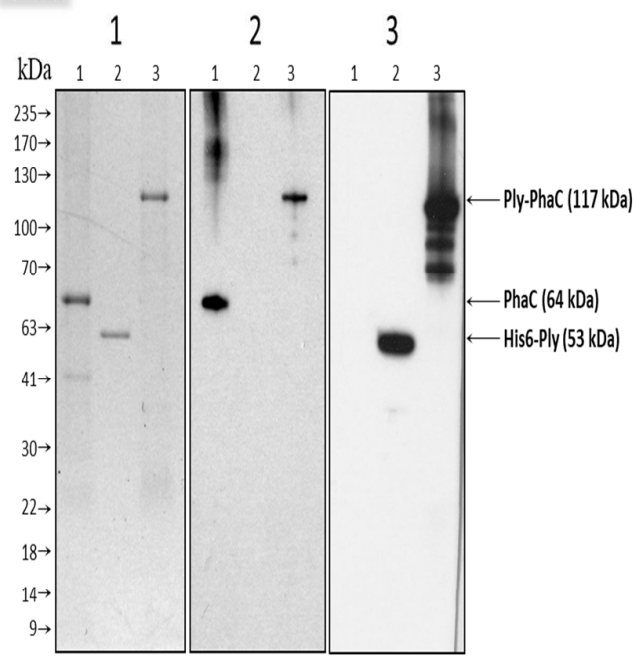

Figure 1. Design, production and characterization of the PHB beads. 1A. Schematic representation of genes encoding proteins relevant to this study. 1A.1, the hybrid gene encoding Ply-PhaC fusion protein mediating PHB bead formation; 1A.2, the gene encoding PhaC mediating non-antigen displaying PHB bead formation; 1A.3, the gene encoding a soluble His6-tagged Ply. B. TEM images of E. coli with PHB inclusions and the corresponding purified PHB beads. 1B.1, cells harboring pET14b-phaC (PhaC wild type, non-antigen displaying); 1B.2, cells harboring pET14b-ply-phaC (Ply-PhaC bead); 1B.3, PhaC beads from cells harboring pET14b-phaC; 1B.4, Ply-PhaC beads derived from cells harboring pET14b-ply-phaC. The white bar represents $500 \mathrm{~nm}$. C. SDS-PAGE and immunoblot analysis of proteins attached to PHB beads as well as purified His6-Ply. 1C.1 Coomassie blue stained SDS-PAGE gel; 1C.2 Immunoblot using polyclonal anti-PhaC antibodies; 1C.3 Immunoblot using monoclonal anti-PLY antibodies (PLY-7). Lane 1, PHB beads isolated from cells harboring pET-14b-phaC encoding PhaC, non-antigen displaying (64 kDa); lane 2, purified His6-Ply (53 kDa) derived from cells harboring pET14b-his6-ply; lane 3, PHB beads isolated from cells harboring pET-14b-ply-phaC encoding Ply-PhaC fusion protein $(117 \mathrm{kDa})$. Molecular weight $(\mathrm{MW})$ standard (GangNam-Stain, iNtRON BIOTECHNOLOGY) was used. The arrows indicate the protein bands of interest with the corresponding theoretical MW in parentheses. 


\section{A}

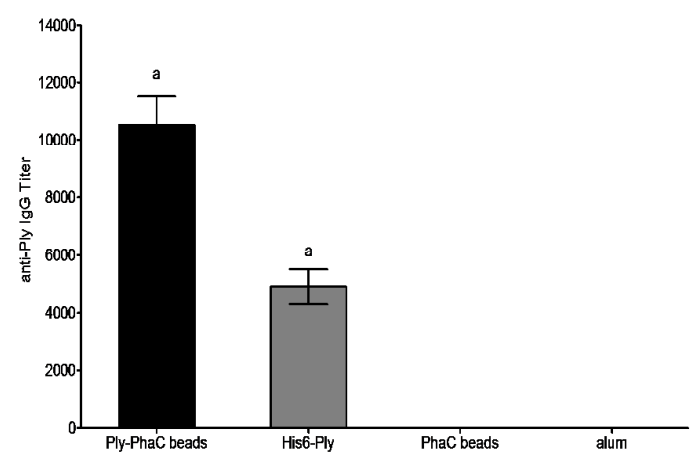

\section{B}

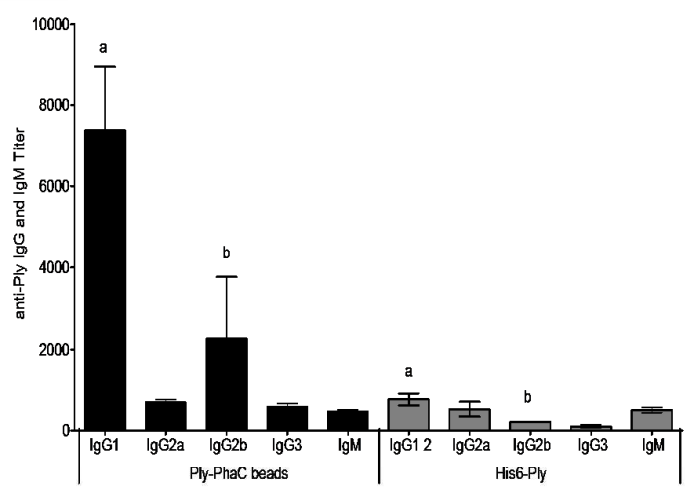

2.C

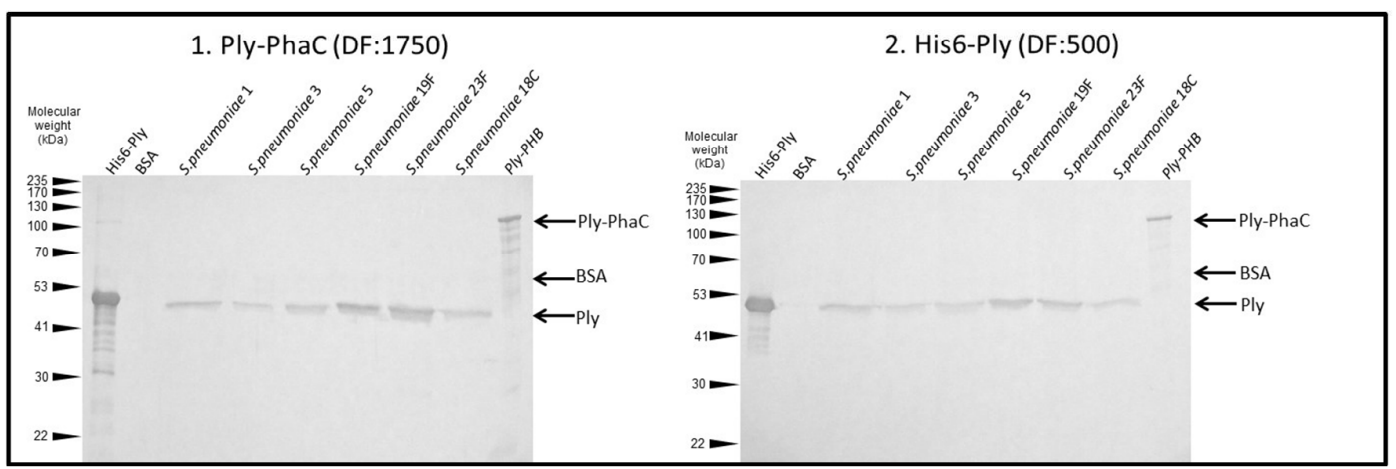

Figure 2. Humoral immune response evaluation against pneumolysin. 2A Analysis of induction of anti-Ply antibodies by various vaccine formulations. Black bar represents sera from mice immunized with $1.5 \mu \mathrm{g}$ of Ply displayed on PHB beads $+15 \mu \mathrm{g}$ of alum; grey bar represent sera from mice immunized with $1.5 \mu \mathrm{g}$ of soluble His6-Ply $+15 \mu \mathrm{g}$ of alum; black line bar represent sera from mice immunized with $1.5 \mu \mathrm{g}$ of PhaC on PHB beads $+15 \mu \mathrm{g}$ of alum (i.e. no antigen PHB bead, negative control); white bar represent mice immunized with $15 \mu \mathrm{g}$ of alum. All immunogens were isolated from an endotoxin-free mutant of $E$. coli. Statistical analysis by the Mann-Whitney test showed that Ply-PhaC beads vs His6-Ply present statistical differences with $p<0.001$. 2B Ig isotypes titers assessed by ELISA. Statistical analysis by Kruskal-Wallis non-parametric test showed: IgG1, Ply-PhaC beads group $>$ His6-Ply group; ${ }^{\mathrm{a}} p<0.05$. While IgG2b, Ply-PhaC beads group $>$ His6-Ply group; ${ }^{\mathrm{b}}$ $p<0.01$. 2C Cross-reactivity of anti-Ply antibodies with Ply from various serotypes of $S$. pneumoniae. 1, immunoblots using pooled sera (diluted 1:1750) from 8 mice immunized with Ply-PhaC beads; 2, immunoblot using pooled sera (diluted 1:500) from 8 mice immunized with soluble His6-Ply. The corresponding SDS-PAGE of whole cell lysates of the various $S$. pneumoniae serotypes is provided in Supplemental Fig. S2. Lane 1, His6-Ply (positive control), Lane 2, BSA (negative control), Lanes 3-8, Whole cell lysates from 6 different $S$. pneumoniae strains, Lane 9, Ply-PhaC beads (control). 


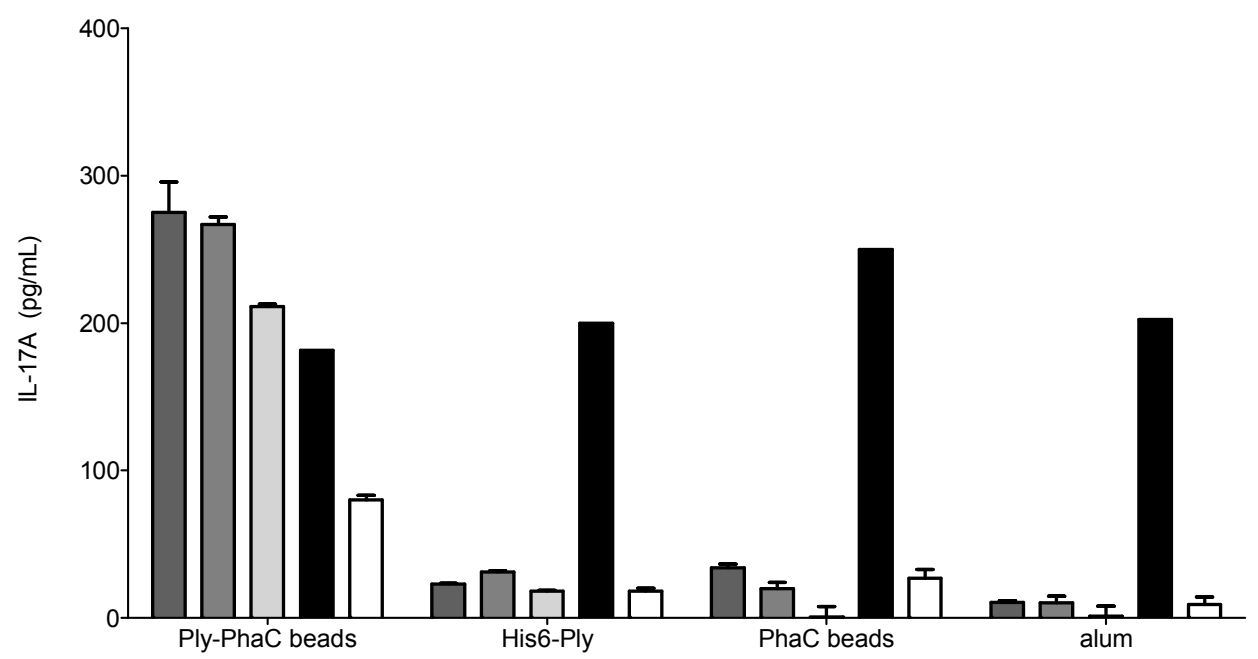

Figure 3. Cytokine profiles induced by various vaccine formulations. Splenocytes were stimulated with His6-Ply $(0.2,5$ or $10 \mu \mathrm{g} / \mathrm{mL})$ and the supernatant of splenocyte cultures was evaluated at different times $(24,48,72$ and $96 \mathrm{~h})$. The results show time $72 \mathrm{~h}$ corresponding to in vitro cytokine production peak. Splenocytes without stimulant were considered as negative controls while cells activated with ConA were considered as positive control. Results are represented as the mean \pm SD of two replicates per group. Data represent one experiment using the splenocytes pool from 8 animals per group. 
4.A

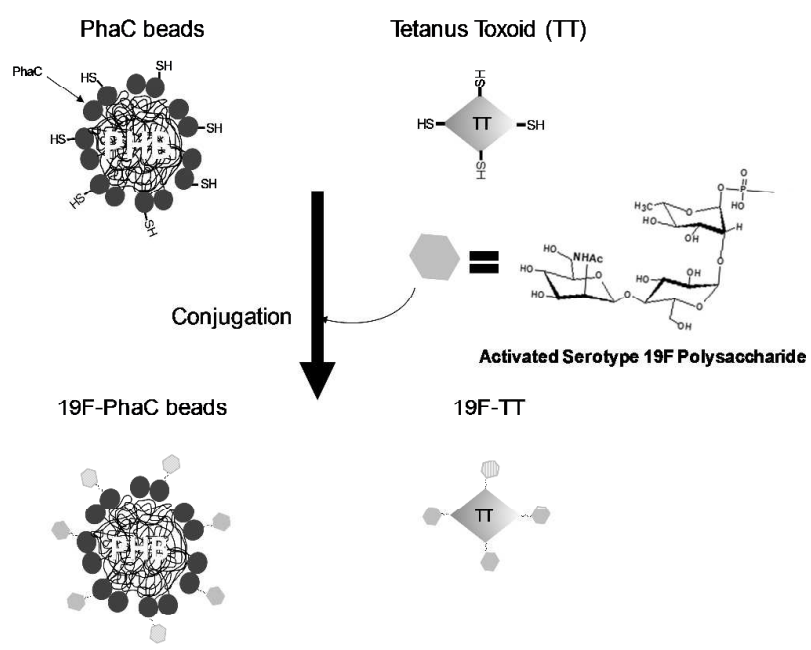

4.B

4.C
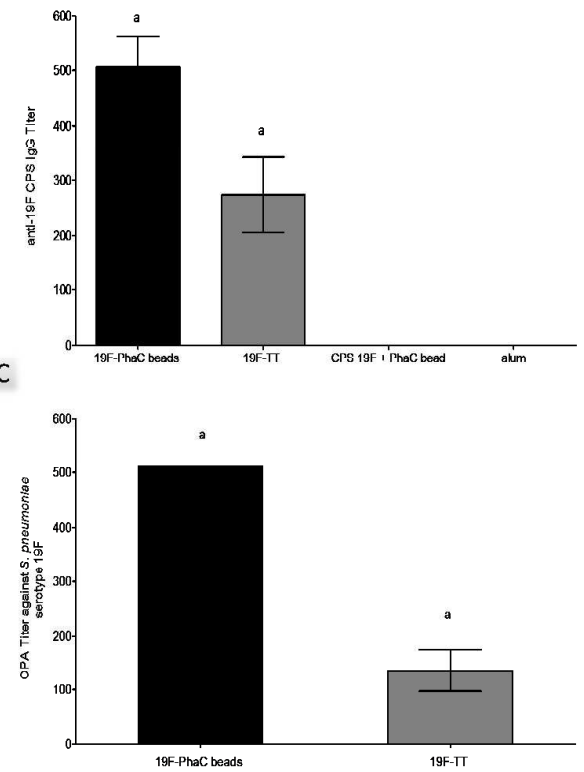

Figure 4. Design, production and immunological characterization of the conjugate PHB beads. 4A Schematic representation of conjugation reaction between activated serotype 19F polysaccharide and PhaC on PHB beads or soluble TT. The repetitive unit of the $19 \mathrm{~F}$ polysaccharide is a trisaccharide of $(\rightarrow 4)-\beta$-D-ManNAc- $(1 \rightarrow 4)-\alpha-\mathrm{D}-\mathrm{Glcp}-(1 \rightarrow 2)-\alpha-\mathrm{L}$ Rhap-1-PO4-). ${ }^{58-60}$ 4B Analysis of anti-19F CPS antibody titers. Black bar, group immunized with $2 \mu \mathrm{g}$ of $19 \mathrm{~F}$ polysaccharide conjugated to PhaC on PHB beads $+125 \mu \mathrm{g}$ of alum; , grey bar, group immunized with $2 \mu \mathrm{g}$ of $19 \mathrm{~F}$ polysaccharide conjugated to $\mathrm{TT}+125 \mu \mathrm{g}$ of alum; black line bar, group immunized with a mix of 19F CPS $(10 \mu \mathrm{g})+\mathrm{PhaC}(30 \mu \mathrm{g})+125 \mu \mathrm{g}$ of alum and white bar, group immunized with $125 \mu \mathrm{g}$ of alum. Statistical analysis using the Mann-Whitney test showed that group 19F-PhaC beads $>19 \mathrm{~F}-\mathrm{TT}$. ${ }^{\mathrm{a}} p<0.01$. 4C The opsonophagocytic activity of sera against $S$. pneumoniae serotype 19F. Black bar, 19F-PhaC beads group immunized with $2 \mu \mathrm{g}$ of $19 \mathrm{~F}$ polysaccharide conjugated to $\mathrm{PhaC}$ wild type beads $+125 \mu \mathrm{g}$ of alum; grey bar 19F-TT, group immunized with $2 \mu \mathrm{g}$ of $19 \mathrm{~F}$ polysaccharide conjugated to TT $+125 \mu \mathrm{g}$ of alum. The assay was performed using serum from each immunized animal/group. Statistical analysis using the Mann-Whitney test showed: group $19 \mathrm{~F}-\mathrm{PhaC}>$ group $19 \mathrm{~F}-\mathrm{TT} .{ }^{\mathrm{a}} p<0.001$. 
FOR TABLE OF CONTENTS USE ONLY

\title{
Design and biological assembly of polyester beads displaying pneumococcal antigens as particulate vaccine
}

\author{
Majela González-Miró, Anna-Maria Radecker, Laura M Rodríguez-Noda, Mildrey Fariñas- \\ Medina, Caridad Zayas-Vignier, Mabel Hernández-Cedeño, Yohana Serrano, Félix Cardoso, \\ Darielys Santana-Mederos, Dagmar García-Rivera, Yury Valdés-Balbín, Vicente Vérez- \\ Bencomo, Bernd H.A. Rehm
}

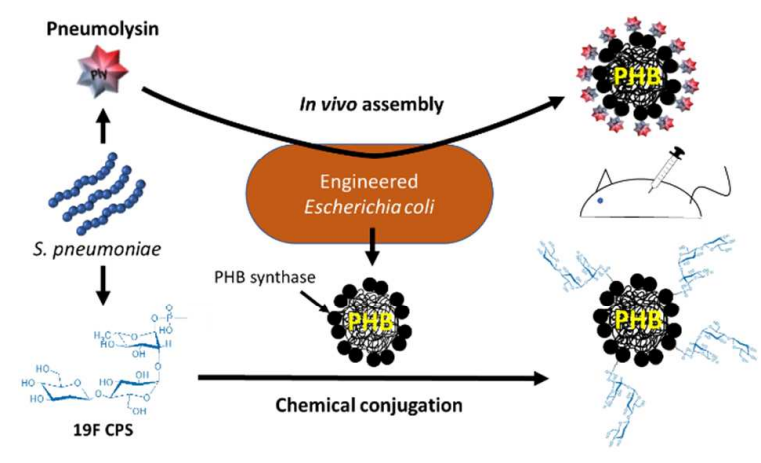


Subscriber access provided by Kaohsiung Medical University

\section{Applications and Health}

\section{Design and biological assembly of polyester beads displaying pneumococcal antigens as particulate vaccine}

Majela Gonzalez Miro, Anna-Maria Radecker, Laura M Rodriguez-Noda, Mildrey Farinas-Medina, Caridad Zayas-Vignier, Mabel Hernández-Cedeño, Yohana Serrano, Félix Cardoso, Darielys SantanaMederos, Dagmar García-Rivera, Yury Valdés-Balbín, Vicente Vérez-Bencomo, and Bernd H. A. Rehm

ACS Biomater. Sci. Eng., Just Accepted Manuscript • DOI: 10.1021/acsbiomaterials.8b00579 • Publication Date (Web): 26 Jul 2018

Downloaded from http://pubs.acs.org on July 30, 2018

\section{Just Accepted}

"Just Accepted" manuscripts have been peer-reviewed and accepted for publication. They are posted online prior to technical editing, formatting for publication and author proofing. The American Chemical Society provides "Just Accepted" as a service to the research community to expedite the dissemination of scientific material as soon as possible after acceptance. "Just Accepted" manuscripts appear in full in PDF format accompanied by an HTML abstract. "Just Accepted" manuscripts have been fully peer reviewed, but should not be considered the official version of record. They are citable by the Digital Object Identifier (DOI®). "Just Accepted" is an optional service offered to authors. Therefore, the "Just Accepted" Web site may not include all articles that will be published in the journal. After a manuscript is technically edited and formatted, it will be removed from the "Just Accepted" Web site and published as an ASAP article. Note that technical editing may introduce minor changes to the manuscript text and/or graphics which could affect content, and all legal disclaimers and ethical guidelines that apply to the journal pertain. ACS cannot be held responsible for errors or consequences arising from the use of information contained in these "Just Accepted" manuscripts. 